\title{
POJAM "UGOVOR O JAVNOJ NABAVI" U PRAVU EUROPSKE UNIJE S POSEBNIM OSVRTOM NA POVEZANE IZNIMKE OD PRIMJENE ZAKONODAVSTVA O JAVNOJ NABAVI
}

Danijel Stanković, mag. iur. *

UDK: 35.073.7:347.4(4)EU

351.712:347.4 (4)EU

339.923:061.1>(4)EU

Pregledni znanstveni rad

Primljeno: listopad 2017.

Tko je i pod kojim uvjetima dužan provesti postupak javne nabave ponajprije ovisi o kvalifikaciji određenog pravnog odnosa kao ugovora o javnoj nabavi. Za takvu se kvalifikaciju moraju ispuniti određene pretpostavke, inače nije riječ o ugovoru o javnoj nabavi. U radu se analiziraju bitna obilježja takvog ugovora kako ih Sud Europske unije tumači u svojoj praksi i novo pravno uređenje iz 2014., koje u nekim aspektima (osobito u pogledu tzv. nabave in house, ugovorne suradnje javnih naručitelja i prijenosa nadležnosti između javnih tijela) izričito odstupa od te prakse.

Ključne riječi: javna nabava, ugovor o javnoj nabavi, nabava in house, ugovorna suradnja javnih naručitelja, prijenos ovlasti i odgovornosti za izvršavanje javnih zadaća

\footnotetext{
Danijel Stanković, mag. iur., LL.M. Finance (Institute for Law and Finance, Goethe-Universität, Frankfurt am Main); LL.M. de droit français et de droit européen (Université Paris 1 Panthéon-Sorbonne), pravnik lingvist na Sudu Europske unije, TB/16LB0022, Rue du Fort Niedergrünewald, L-2925 Luxembourg; danijel.stankovic@curia.europa.eu;
}

ORCID ID: orcid.org/0000-0003-0551-7394

Autor u ovom članku iznosi svoje vlastite stavove koji ni na koji način ne predstavljaju službeno stajalište Suda EU-a na kojem trenutačno radi. 


\section{UVOD}

Predmet je ovog članka analiza pojma "ugovor o javnoj nabavi” u pravu Unije i njegovih bitnih obilježja kako ih Sud Europske unije tumači u svojoj praksi i s tim povezanih iznimki od primjene zakonodavstva o javnoj nabavi. S tim u vezi valja naglasiti da je riječ o autonomnom pojmu prava Unije, pa su definicije "ugovora" prema nacionalnim pravima država članica irelevantne. ${ }^{2}$

Navedena analiza ponajprije se temelji na odredbama petog javnonabavnog regulatornog okvira iz 2014. ${ }^{3}$, pa se prethodni regulatorni okviri - osim povremenih usporedbi - zbog opsega rada ne obrađuju detaljno. ${ }^{4}$

Kao što će biti prikazano u ovom radu, širokim, funkcionalnim i dosljednim tumačenjem bitnih obilježja ugovora o javnoj nabavi i istodobno uskim tumačenjem iznimki od tih obilježja nastoji se spriječiti izbjegavanje primjene zakonodavstva o javnoj nabavi kojemu je jedan od glavnih ciljeva otvaranje tržišta javne nabave što većem tržišnom natjecanju. ${ }^{5}$

1 Engl. public contract, fr. marché public, njem. öffentlicher Auftrag.

2 Auroux i dr. (C-220/05, EU:C:2007:31, t. 40); Komisija/Italija (C-382/05, EU:C:2007:445, t. 30) i Asociación Profesional de Empresas de Reparto y Manipulado de Correspondencia (C-220/06, EU:C:2007:815, t. 50, dalje u tekstu: Correos).

3 Direktiva 2014/24/EU o javnoj nabavi i o stavljanju izvan snage Direktive 2004/18/ EZ (SL 2014., L 94, str. 65, te ispravci SL 2015., L 275, str. 68, i SL 2016., L 311, str. 26, dalje u tekstu: opća direktiva o javnoj nabavi); Direktiva 2014/25/EU o nabavi subjekata koji djeluju u sektoru vodnog gospodarstva, energetskom i prometnom sektoru te sektoru poštanskih usluga i stavljanju izvan snage Direktive 2004/17/ EZ (SL 2014., 94, str. 243) naziva se sektorskom direktivom o nabavi jer se odnosi na posebne djelomično liberalizirane sektore u kojima je još uvijek dominantan javni interes (dalje u tekstu: direktiva o sektorskoj nabavi); Direktiva 2014/23/EU o dodjeli ugovorâ o koncesiji (SL 2014., L 94, str. 1, i ispravak SL 2015., L 114, str. 24) (dalje u tekstu: direktiva o koncesijama); u cijelom tekstu navedene se direktive zajedno nazivaju "direktive o javnoj nabavi".

$4 \mathrm{U}$ pogledu prethodnih javnonabavnih regulatornih okvira vidjeti Turudić, M., Pravo javne nabave, Narodne novine, Zagreb, 2017., str. 31 - 43.

5 Vidjeti primjerice presude CoNISMa (C-305/08, EU:C:2009:807, t. 37 i 43); Swm Costruzioni 2 i Mannocchi Luigino (C94/12, EU:C:2013:646, t. 34); Data Medical Service (C-568/13, EU:C:2014:2466, t. 34), Partner Apelski Dariusz (C-324/14, EU:C:2016:214, t. 34). 


\section{POJAM "UGOVOR O JAVNOJ NABAVI"}

Ugovor o javnoj nabavi temeljni je institut prava javne nabave koji označava poseban javnopravni odnos između javnog naručitelja i gospodarskog subjekta, uređen primarnim i sekundarnim pravom Unije te nacionalnim pravima država članica. Navedeni ugovor mogao bi se općenito definirati kao pravni posao kojim javni naručitelj drugom subjektu povjerava izvršenje određenog posla ili poslova koji se sastoje od izvođenja radova, nabave robe ili pružanja usluga. U tom smislu, člankom 2. stavkom 1. točkom 5. opće direktive o javnoj nabavi predviđeno je da pojam "ugovor o javnoj nabavi" obuhvaća (i) ugovorne odnose, (ii) "kojima se ostvaruje financijski interes", (iii) koji su sklopljeni u pisanom obliku, (iv) između jednog ili više gospodarskih subjekata i jednog ili više javnih naručitelja, a (v) čiji je predmet izvođenje radova, nabava robe ili pružanje usluga.

Kao što je vidljivo, ponajprije mora biti riječ o ugovornom odnosu, što znači da su druge vrste pravnih odnosa isključene. Kao drugo, mora biti riječ o naplatnom pravnom poslu. Kao treće, ugovor načelno mora biti sklopljen u pisanom obliku. Kao četvrto, mora biti riječ o ugovoru između javnog naručitelja i jednog ili više točno određenih gospodarskih subjekata ${ }^{7}$ odabranih u odgovarajućem postupku nadmetanja. ${ }^{8}$ I na kraju, kao peto, predmet ugovora mora biti izvođenje radova, nabava robe ili pružanje usluga. To su bitna obilježja svakog ugovora o javnoj nabavi koja moraju biti kumulativno ispunjena. U protivnom nije riječ o ugovoru o javnoj nabavi.

Svako od navedenih obilježja uključuje pojmove koji zahtijevaju daljnje definicije i tumačenja, što u praksi stvara brojne poteškoće u slučaju graničnih

Engl. for pecuniary interest, fr. à titre onéreux, njem. entgeltlich.

Koji također mogu imati svojstvo javnog naručitelja (o tome više infra 2.4.).

8 S tim u vezi treba naglasiti da ugovor o javnoj nabavi podrazumijeva odnos isključivosti, pa drugi inovativni oblici, poput ugovaranja sa svim zainteresiranim gospodarskim subjektima koji ne podrazumijevaju odabir uspješnog ponuditelja i sklapanje isključivog ugovora s njim (tzv. open house model), nisu ugovor o javnoj nabavi. U tom je pogledu Sud utvrdio "da je izbor ponude, a time i uspješnog ponuditelja, element bitno povezan s uređenjem javne nabave [općom direktivom o javnoj nabavi] i, slijedom toga, s pojmom 'ugovora o javnoj nabavi'”, pa "neodređivanje gospodarskog subjekta kojem bi bio dodijeljen [...] ugovor ima za posljedicu to da nema potrebe detaljnim propisima [navedene direktive] regulirati [konkretno] postupanje [...] javnog naručitelja", Falk Pharma (C-410/14, EU:C:2016:399, t. 37 i 38). Vidjeti također Schabel, T., Vergaberechtsfreiheit des Open-House-Modells, Europäische Zeitschrift für Wirtschaftsrecht, br. 18, 2016., str. 708 - 709, i Gaßner, M., Das Open-house-Urteil des EuGH - Ein Geschenk für kreative Beschaffer, Neue Zeitschrift für Sozialrecht, br. 20, 2016., str. $767-770$. 
situacija. Stoga treba biti oprezan prilikom strukturiranja konkretnog odnosa jer on može i nehotice ispuniti sva obilježja ugovora o javnoj nabavi i tako izložiti sve sudionike konkretnog posla ili projekta riziku uspješnog pobijanja u odgovarajućim pravnim postupcima. Naime, riječ je o funkcionalnom, a ne o formalnom pristupu u pogledu definicije ugovora o javnoj nabavi. ${ }^{9}$

U nastavku se bitna obilježja pojedinačno analiziraju redom kako se navode u definiciji iz opće direktive o javnoj nabavi. U okviru analize pojedinačnih obilježja povezane se iznimke predstavljaju u pravilu kronološki, kako su nastajale u sudskoj praksi Suda EU-a.

\subsection{Prvo obilježje: ugovorni odnos}

Nakon uvodne pozitivne definicije pojma "ugovor o javnoj nabavi" u vezi s prvim obilježjem analiziraju se situacije koje nisu obuhvaćene tim pojmom: (a) druge vrste javnopravnih odnosa i (b) izvršavanje ovlasti koje izravno proizlaze iz zakona.

Riječ je o situacijama u kojima je odnos između javnog naručitelja i gospodarskog subjekta ili drugog javnog naručitelja takav da sam po sebi ne ispunjava pretpostavku postojanja ugovornog odnosa. To su vertikalni javnopravni odnosi između javnog naručitelja i gospodarskog subjekta ili drugog javnog naručitelja koji po prirodi stvari nisu obuhvaćeni pojmom "ugovor o javnoj nabavi", a mogu se temeljiti na (i) jednostranom upravnom aktu javnopravnog tijela ili (ii) izravno na zakonu. ${ }^{10}$

\subsubsection{Javnopravni odnos na temelju jednostranog upravnog akta}

Sud EU-a utvrdio je u presudama Asemfo i Correos razliku između javnopravnog odnosa, u kojem se neki gospodarski subjekt nalazi u potpuno podređenom položaju prema upravi, i ugovornog odnosa. ${ }^{11}$

9 Wiggen, J., Public procurement rules and cooperation between public sector entities: the limits of the in-house doctrine under EU procurement law, Public Procurement Law Review, br. 5, 2011., str. 159.

10 Ibid., str. 168 - 171.

11 Probst, P.; Wurzel, G., Zulässigkeit von In-house-Vergaben und Rechtsfolgen des Abschlusses von vergaberechtswidrigen Verträgen, European Law Reporter, br. 7-8, 2007., str. 260; Müller, T., Interkommunale Zusammenarbeit im Weg der In-House-Vergabe?, Zeitschrift für Vergaberecht und Beschaffungspraxis, vol. 7-8, 2007., str. 202, i Wiggen, J., op. cit. u bilj. 9, str. 170 . 
U predmetu Asemfo prvo obilježje ugovora o javnoj nabavi nije bilo ostvareno s obzirom na to da trgovačko društvo kojemu je povjeren posao uopće nije imalo slobodu ni u pogledu prihvaćanja narudžbi nadležnih tijela ni u pogledu određivanja cijena za svoje činidbe. ${ }^{12}$ Naime, u konkretnom je slučaju gospodarski subjekt morao prihvaćati naredbe i upute javnog tijela - većinskog člana društva - pa je zapravo bio samo njegovo sredstvo ili tehnička služba. ${ }^{13}$ Sud je pritom analizirao cjelokupni pravni okvir koji se primjenjivao na odnose javnog tijela i dotičnog društva ${ }^{14}$, pa se tu iznimku, bez takvog popratnog pravnog okvira, ne bi moglo lako primijeniti na druge izravne dodjele. ${ }^{15}$

Zato je Sud u predmetu Correos odbio primijeniti svoje stajalište iz presude Asemfo na slučaj koji se odnosio na španjolsku poštu kao pružatelja univerzalnih usluga. ${ }^{16} \mathrm{U}$ tom je pogledu Sud najprije istaknuo da to što neki gospodarski subjekt (u konkretnom slučaju španjolska pošta) nema slobodu ni u pogledu prihvaćanja narudžbi javnopravnog tijela ni u pogledu određivanja cijena za svoje činidbe ne znači automatski da nije sklopljen ugovor između tih dvaju subjekata. ${ }^{17}$ Sud je naglasio da se u tom slučaju položaj javnog naručitelja koji je pošti povjerio određene poslove ne razlikuje ni od kojeg drugog privatnopravnog klijenta koji se koristi poštanskim uslugama. ${ }^{18}$ Sud je također precizirao da ugovorni odnos ne postoji samo ako je riječ o jednostranom upravnom aktu javnopravnog tijela kojim se gospodarskom subjektu nalažu obveze isključivo na njegov teret, kao što je to bio slučaj u presudi Asemfo. ${ }^{19}$ Iz toga je vidljiv dosljedan stav Suda u pogledu uskog tumačenja iznimki od primjene zakonodavstva o javnoj nabavi.

12 Asociación Nacional de Empresas Forestales (C-295/05, EU:C:2007:227, dalje u tekstu: Asemfo, t. 51 i 54).

13 Ibid., t. 53.

14 Ibid., t. $49-51$.

15 Janssen, W. A., The Institutionalised and Non-Institutionalised Exemptions from EU Public Procurement Law: Towards a More Coherent Approach?, Utrecht Law Review, vol. 10., br. 5, 2014., str. 173, napomena u bilješci 93.

16 Fruhmann, M., Der gemeinschaftsrechtliche Vertragsbegriff, In-House und das Transparenzprinzip, Zeitschrift für Vergaberecht und Beschaffungspraxis, vol. 3, 2008, str. 74 - 76; McGowan, D., A Contract or Not?, Public Procurement Law Review, br. 5, 2008., str. NA207-NA208, i Wiggen, J., op. cit. u bilj. 9, str. 168 - 170.

17 Correos (bilj. 2, t. 53); Fruhmann, M., op. cit. u bilj. 16, str. 74. Riječ je o situaciji koja je slična onima iz članka 248. Zakona o obveznim odnosima (Narodne novine, br. 35/2005, 41/2008, 125/2011, 78/2015), koji se odnosi na obvezno sklapanje i obvezni sadržaj ugovora.

18 Correos (bilj. 2, t. 54).

19 Ibid., t. 54. 


\subsubsection{Izvršavanje ovlasti koje izravno proizlaze iz zakona}

Nasuprot tomu, Sud je bio benevolentniji u pogledu situacija javno-javne suradnje ${ }^{20} \mathrm{u}$ kojima jedan javni subjekt na temelju vlastitih zakonskih ovlasti obavlja određene poslove iz djelokruga drugog javnog subjekta i za to od njega dobiva određenu naknadu (subvenciju). ${ }^{21}$

U presudi Komisija/Irska Sud je zaključio da izvršavanje zakonskih ovlasti, bez obzira na sufinanciranje drugog tijela na temelju ugovora o suradnji, ne ispunjava pretpostavke za postojanje "ugovora o javnoj nabavi" između tog tijela kao javnog naručitelja i Grada Dublina. ${ }^{22}$ Takvo stajalište moglo bi se u određenim okolnostima opravdati i iznimkom od sloboda poslovnog nastana i pružanja usluga predviđenih člankom 51. u vezi s člankom 62. Ugovora o funkcioniranju Europske unije (u daljnjem tekstu: UFEU) u korist djelatnosti povezanih s izvršavanjem javnih ovlasti. ${ }^{23}$ Ta je iznimka u biti srodna i s onom iz predmeta Remondis u pogledu prijenosa ovlasti i odgovornosti za izvršavanje javnih zadaća (vidjeti infra 2.4.3.) ${ }^{24}$, iako je ovdje riječ o financiranju i obavljanju takvih djelatnosti u skladu s već zatečenom raspodjelom nadležnosti između javnih tijela. S tim u vezi moglo bi se zaključiti da u takvim situacijama nedostaje i obilježje naplatnosti s obzirom na to da nije riječ o plaćanju naknade za usluge, nego o sufinanciranju javnih zadaća. ${ }^{25}$

Od tog slučaja valja razlikovati izvršavanje zakonskih ovlasti predviđenih u korist privatnog poduzetnika koje načelno ne isključuje primjenu pravila o javnoj nabavi. Tako je u ranijoj presudi Ordine degli Architetti i $d r$. Sud ocijenio da na ugovorni karakter odnosa između javnog naručitelja i privatnog investitora ne utječe to što je potonji u okviru provedbe privatnog projekta na temelju

20 O drugim oblicima takve suradnje više vidjeti infra 2.4.1., 2.4.2 i 2.4.3.

21 Wiggen, J., op. cit. u bilj. 9, str. 168 - 171.

22 Komisija/Irska (C-532/03, EU:C:2007:801, t. 35 i 37). U tom smislu vidjeti također Wiggen, J., op. cit. u bilj. 9, str. 165 - 167.

23 Kao što je to pravilno primijetio i Oberlandesgericht Düsseldorf u svojem zahtjevu za prethodnu odluku u predmetu Piepenbrock (C-386/11, EU:C:2013:385, t. 19), iako je u tom slučaju bila riječ o suprotnoj situaciji.

24 Wiggen, J., op. cit. u bilj. 9, str. 165 - 167, i zaključci Suda u presudi Remondis (C-51/15, EU:C:2016:985, t. 40, 41, 49 i 50), iako s pozivom na članak 4. stavak 2. Ugovora o Europskoj uniji (u daljnjem tekstu: UEU) prema kojem je Unija dužna poštovati nacionalne identitete država članica, koji su neodvojivo povezani s njihovim temeljnim političkim i ustavnim strukturama, uključujući regionalnu i lokalnu samoupravu.

25 Wiggen, J., op. cit. u bilj. 9, str. 167, i Remondis (bilj. 24, t. 50 - 52). 
zakona ovlašten izravno izvesti radove na izgradnji komunalne infrastrukture za račun lokalne jedinice. ${ }^{26}$

Istu je sudsku praksu Sud potvrdio u presudi Eric Libert i $d r$., u kojoj je privatni investitor koji je s lokalnom jedinicom sklopio ugovor o uređenju građevinskog zemljišta ${ }^{27}$ na temelju nacionalnog zakonodavstva bio dužan (i ovlašten) izgraditi određen broj socijalnih stanova. ${ }^{28}$ Drugim riječima, i u takvim slučajevima, $\mathrm{u}$ kojima je privatni investitor izravno na temelju zakona ovlašten provesti određene radove, može biti riječ o ugovoru o javnoj nabavi za koji je potrebno prethodno provesti postupak javne nabave. ${ }^{29}$

Ipak, od tog slučaja svakako treba razlikovati projekte u kojima privatni investitor od javnog tijela kupuje izgrađeno ili neizgrađeno zemljište isključivo zbog razvoja svojeg projekta koji ne uključuje radove na izgradnji javne infrastrukture, ali podrazumijeva određene izmjene $u$ prostornim planovima. ${ }^{30}$

\subsection{Drugo obilježje: naplatnost}

Bitno je obilježje ugovora o javnoj nabavi njegova naplatnost. Drugim riječima, besplatne činidbe u korist javnih naručitelja nisu obuhvaćene pojmom ugovora o javnoj nabavi. Drugo je pitanje jesu li takve činidbe konkretno dopuštene u korist javnog naručitelja. ${ }^{31}$ Međutim, budući da se u praksi javlja niz graničnih

26 Ordine degli Architetti i dr. (C-399/98, EU:C:2001:401, t. 69 i 71); Würfel, W.; Butt, M., Ausschreibungspflicht für städtebauliche Verträge - oder: Schaut man einem geschenkten Gaul doch ins Maul?, Neue Zeitschrift für Verwaltungsrecht, vol. 2, 2003., str. 153.

Engl. development agreement, fr. convention de lotissement, njem. Erschließungsvertrag.

28 Eric Libert i dr. (C-197/11 i C-203/11, EU:C:2013:288, t. 108 - 115).

29 Brown, A., Whether an Obligation on Certain Property Developers in Belgium to Provide Social Housing Gave Rise to a Public Works Contract Within Directive 2004/18, Public Procurement Law Review, br. 6, 2013., str. NAl67 - NAl72.

Vidjeti u tom smislu presudu Helmut Müller (C-451/08, EU:C:2010:168).

31 Primjerice, u članku 68. Zakona o financiranju vodnog gospodarstva (Narodne novine, br. 153/2009, 90/2011, 56/2013, 154/2014, 119/2015, 120/2016) izričito je predviđeno da se gradnja i održavanje vodnih građevina može sufinancirati ili financirati, među ostalim, darovima fizičkih i pravnih osoba, dok člankom 30. Zakona o komunalnom gospodarstvu (Narodne novine, br. 36/1995, 70/1997, 128/1999, 57/2000, 129/2000, 59/2001, 26/2003, 82/2004, 110/2004, 178/2004, 38/2009, 79/2009, 153/2009, 49/2011, 84/2011, 90/2011, 144/2012, 94/2013, 153/2013, $147 / 2014,36 / 2015$ ) u pogledu građenja objekata i uređaja komunalne infrastrukture nije predviđena takva mogućnost, osim ako se eventualno osnova za takvo financiranje može pronaći u nekom drugom posebnom zakonu. 
situacija, javni naručitelji ih često pokušavaju prikazati kao da je riječ o besplatnim činidbama kako bi se izbjegla primjena pravilâ o javnoj nabavi. Pritom valja napomenuti da vrijednost predmeta nabave iznad određenog praga nije bitno obilježje ugovora o javnoj nabavi, nego pretpostavka za primjenu direktiva o javnoj nabavi.

U sudskoj praksi pojavile su se tri vrste situacija u kojima se postavilo pitanje naplatnosti ugovora: (i) situacije u kojima gospodarski subjekt javnom naručitelju daruje neku vrijednost (nekretninu ili određeni novčani iznos) za koju mu zatim javni naručitelj umanjuje iznos javnih davanja koje bi on inače morao platiti, (ii) situacije u kojima se gospodarski subjekt u cijelosti ili djelomice naplaćuje od trećih osoba i (iii) situacije u kojima javni naručitelj gospodarskom subjektu pokriva isključivo osnovne troškove pružanja usluge, a da potonji pritom uopće ne ostvaruje dobit.

Prva vrsta situacija veže se uz predmet Ordine degli Architetti i dr., u kojem je vlasnik zemljišta kao nositelj privatnog projekta prema talijanskom zakonodavstvu mogao biti i investitor komunalne infrastrukture za račun lokalne jedinice, dok se ta jedinica istodobno odrekla potraživanja komunalnog doprinosa u vrijednosti prenesene joj imovine. ${ }^{32}$ Sud je s tim u vezi zauzeo stajalište prema kojem odricanje lokalne jedinice od doprinosa koji bi privatni investitor inače morao platiti pokazuje da je riječ o naplatnom ugovoru. ${ }^{33}$

Navedeni zaključak poprilično je zakomplicirao provedbu velikih projekata u praksi, s obzirom na to da je većina privatnih investitora spremna sama financirati uređenje građevinskog zemljišta i što prije izgraditi potrebnu komunalnu infrastrukturu, ali je Sud ovdje očito želio zaštititi javni interes da dio radova koji bi općina trebala sama obaviti bude dodijeljen transparentno i uz poštovanje propisa o javnoj nabavi. ${ }^{34}$

Druga je vrsta situacija još osjetliivija jer u njima gospodarski subjekt ne prima naknadu izravno od javnog naručitelja, nego od korisnika objekta koji će se izgraditi ili korisnika usluge koju treba pružiti, slično kao u slučaju koncesija. To je pitanje Sud obradio u presudi Auroux i dr., u kojoj je bila riječ o povjeravanju poslova izgradnje posebnoj pravnoj osobi koja je prema mjerodavnim kriterijima

32 Slična je mogućnost predviđena sada u članku 165. Zakona o prostornom uređenju (Narodne novine, br. 153/2013). Međutim, za razliku od tadašnjeg talijanskog propisa, člankom 167. stavkom 4. općenito je predviđeno da sklapanje ugovora o financiranju uređenja građevinskog zemljišta ne isključuje primjenu posebnih propisa o javnoj nabavi.

33 Ordine degli Architetti i dr. (bilj. 26, t. 76 - 86).

34 Würfel, W.; Butt, M., op. cit. u bilj. 26, str. 156 - 158. 
također imala svojstvo javnog naručitelja. Međutim, budući da nisu bili ispunjeni kriteriji tzv. nabave in house ${ }^{35}$, takav se ugovor nije mogao izuzeti od obveze provođenja postupka javne nabave. Stoga je Sud analizirao i pitanje naplatnosti tog ugovora, pri čemu je došao do potvrdnog zaključka, s obzirom na to da je (i) ugovaratelj primao naknadu od javnog naručitelja za ustupljeni objekt, (ii) javni naručitelj sudjelovao u svim troškovima izgradnje i (iii) ugovaratelj imao pravo primati naknadu odnosno zakupninu od trećih osoba za ustupanje dijela izgrađenih objekata. ${ }^{36}$ Sud je utvrdio da ne postoji pravilo prema kojem bi iznose koji se uzimaju u obzir prilikom izračuna vrijednosti predmeta nabave trebalo ograničiti isključivo na primitke od javnog naručitelja. ${ }^{37}$ Sud je zaključio da interes mogućeg ponuditelja treba vezati uz ukupnu vrijednost projekta, što uključuje i primitke od trećih osoba. ${ }^{38} \mathrm{U}$ suprotnom bi slučaju javni naručitelj mogao bez provedbe postupka javne nabave dodijeliti ugovor kojemu ukupna vrijednost predmeta nabave prelazi propisani prag, a za koji bi mogli biti zainteresirani i drugi poduzetnici aktivni u tom području. ${ }^{39}$

U pogledu treće vrste situacija iz sudske prakse proizlazi da neki ugovor ne može biti izuzet od primjene pojma "ugovor o javnoj nabavi" samo zato što je predviđena naknada ograničena na naknadu troškova nastalih prilikom obavljanja ugovorenog posla. ${ }^{40}$

35 Više o toj iznimci vidjeti infra 2.4., a tiče se četvrtog bitnog obilježja ugovora o javnoj nabavi.

36 Auroux i dr. (bilj. 2, t. 45).

37 Ibid., t. 50.

38 Ibid., t. 54.; Kahlert, H., Auftragswert bei der Vergabe städtebaulicher Entwicklungsaufträge: Einbeziehung von Zahlungen privater Erwerber, European Law Reporter, br. 2, 2007., str. 73 .

Ibid., t. 55.

40 Ordine degli Ingegneri della Provincia di Lecce i dr. (C-159/11, EU:C:2012:817, t. 29, dalje u tekstu: Lecce), Piepenbrock (bilj. 23, t. 31) i Azienda sanitaria locale n. 5 "Spezzino" i dr. (C-113/13, EU:C:2014:2440, t. 37). Sud je, međutim, u potonjoj presudi (t. 58 - 62) odobrio takvu iznimku u prilog propisu koji je prednost pri dodjeljivanju ugovora o javnoj nabavi usluga hitnog sanitetskog prijevoza davao volonterskim organizacijama. U tom je slučaju bila riječ o iznimci na temelju važnog razloga u općem interesu koji se tiče sustava javnog zdravstva i socijalne sigurnosti, ibid., t. 55 - 59; Broussy, E.; Cassagnabère, H.; Gänser, C., Attribution sans mise en concurrence d'un marché public à une association sans but lucratif, L'actualité juridique: droit administratif, br. 6, 2015., str. 333 - 334 . 


\subsection{Treće obilježje: pisani oblik ugovora}

U pogledu pisanog oblika ugovora o javnoj nabavi prije je riječ o obvezi poštovanja određene forme pravnog posla nego o pretpostavci koja, ako nije ispunjena, dovodi do zaključka da ne postoji ugovor o javnoj nabavi. U suprotnom slučaju zaobilaženje propisa o javnoj nabavi izravnim dodjelama poslova nabave bilo bi moguće sasvim jednostavno ostvariti usmenim dogovorima, što bi sigurno bilo protivno obvezi transparentnosti koju je Sud na temelju zabrane diskriminacije na osnovi državljanstva protegnuo na sve ugovore o javnoj nabavi bez obzira na vrijednost njihova predmeta nabave, dakako pod uvjetom da postoji određen prekogranični interes. ${ }^{41}$

Budući da je riječ o odnosu javnog naručitelja i gospodarskih subjekata ili odnosu nekoliko javnih naručitelja, teorijski je također nezamisliv slučaj u kojem bi se javnim novcem valjano raspolagalo na temelju usmenih dogovora. $U$ svakom slučaju, to bi činilo povredu proračunske discipline javnog naručitelja. ${ }^{42}$

Kao što je gore navedeno, Sud je zaključio da je ta pretpostavka ispunjena i u vezi sa situacijama u kojima je privatni investitor bio ovlašten izravno na temelju zakona izvesti određene radove za račun lokalne jedinice, upućujući pritom na neki drugi, prethodni ugovor ili sporazum između teritorijalne jedinice i privatnog investitora. ${ }^{43}$

\section{4. Četvrto obilježje: ugovor sklopljen između dviju različitih osoba (jednog ili više javnih naručitelja $i$ jednog ili više gospodarskih subjekata)}

U pogledu područja primjene ratione personae sukladno općoj direktivi o javnoj nabavi mora biti riječ o ugovoru između jednog ili više javnih naručitelja i jednog ili više gospodarskih subjekata. Drugim riječima, stranke ugovora o javnoj nabavi moraju biti dvije pravno različite osobe.

Pritom valja naglasiti da to nije nužno samo odnos između javnog i privatnog subjekta, nego se i različiti oblici suradnje javnih subjekata mogu podvesti pod pojam ugovora o javnoj nabavi. Naime, iako se na prvi pogled može činiti da je iz pojma "ugovor o javnoj nabavi" po prirodi stvari izuzeta svaka suradnja

41 Komisija/Belgija (C-87/94, EU:C:1996:161), Unitron Scandinavia i 3-S (C-275/98, EU:C:1999:567) i Borta (C-298/15, EU:C:2017:266).

42 Grifoni/EZAE (C-330/88, EU:C:1991:95).

43 Ordine degli Architetti i dr. (bilj. 26, t. 69 i 71) i Eric Libert i dr. (bilj. 28, t. 108 115). 
javnih tijela, koja se često odvija u pravnom okviru upravnog ili javnog prava, u sudskoj praksi Suda EU-a svako se povjeravanje određenog posla uz naplatu između dvaju javnih tijela - zbog široke definicije gospodarskog subjekta - načelno smatra ugovorom o javnoj nabavi. ${ }^{44}$ Svaka iznimka od provedbe postupka javne nabave u sudskoj se praksi vrlo usko tumači, a teret dokazivanja je na osobi koja se na nju poziva ${ }^{45}$ Zbog toga se ovdje najprije ukratko analiziraju definicije subjekata javne nabave.

Kao prvo, prema članku 2. stavku 1. točki 1. opće direktive o javnoj nabavi pojam “javni naručitelj” znači: "država, regionalne ili lokalne vlasti, javnopravna tijela, udruženja koja je osnovala jedna ili nekoliko takvih vlasti ili jedno ili nekoliko takvih javnopravnih tijela".

Kao drugo, prema članku 2. stavku 1. točki 10. opće direktive o javnoj nabavi: “'gospodarski subjekt' znači fizička ili pravna osoba ili javno tijelo ili skupina tih osoba i/ili tijela, uključujući svako privremeno udruženje poduzeća, koja na tržištu nudi izvođenje radova i/ili posla, isporuku robe ili pružanje usluga".

Ovdje treba istaknuti razliku između pojmova "javnopravno tijelo"46 iz prve i “javno tijelo"47 iz druge definicije. Prema članku 2. stavku 1. točki 4. navedene direktive javnopravno tijelo svako je tijelo koje kumulativno ispunjava sljedeće pretpostavke: (a) uspostavljeno je posebno u svrhu zadovoljavanja potreba u općem interesu koje nisu industrijske ili trgovačke naravi, (b) ima pravnu osobnost i (c) većim ga dijelom financiraju "država, regionalna ili lokalna tijela ili druga javnopravna tijela ili su podložna upravljačkom nadzoru od strane tih tijela ili imaju upravni, upraviteljski ili nadzorni odbor, a više od polovice članova tih odbora imenovala je država, regionalna ili lokalna tijela ili druga javnopravna tijela”. To su uglavnom samostalne upravne organizacije, ali i druge pravne osobe koje ispunjavaju druge dvije navedene pretpostavke u pogledu svojeg financiranja i upravljanja.

44 Teckal (C-107/98, EU:C:1999:562, t. 51), ARGE Gewässerschutz (C-94/99, EU:C:2000:677, t. 40), CoNISMa (bilj. 5, t. 38); Lecce (bilj. 40, t. 26) i Undis Servizi (C-553/15, EU:C:2016:935, t. 28).

45 Stadt Halle RPL Lochau (C-26/03, EU:C:2005:5, t. 46, dalje u tekstu: Stadt Halle), Parking Brixen (C-458/03, EU:C:2005:605, t. 63), ANAV (C-410/04, EU:C:2006:237, t. 26), Datenlotsen Informationssysteme (C-15/13, EU:C:2014:303, t. 23, dalje u tekstu: Datenlotsen) i Undis Servizi (bilj. 44, t. 29).

46 Engl. body governed by public law, fr. organisme de droit public, njem. öffentliche Einrichtung.

47 Engl. public entity, fr. entité publique, njem. Einrichtung des öffentlichen Rechts. 
U pogledu pojma “javnopravno tijelo" Sud zagovara široko tumačenje, no u svakom pojedinom slučaju treba provjeriti pravni i faktični položaj konkretnog subjekta kako bi se ispitalo zadovoljava li opći interes. ${ }^{48}$

Međutim, važno je naglasiti da pojam "javno tijelo" u skladu sa sudskom praksom Suda obuhvaća i javnopravna tijela i državu i teritorijalne jedinice, tj. druge javne naručitelje. Naime, pojam "gospodarski subjekt" iz svojeg dosega ne isključuje izričito "javne naručitelje", pa se i ugovor o nabavi između dvaju javnih naručitelja također u pravilu smatra ugovorom o javnoj nabavi, osim ako su ispunjene pretpostavke za tzv. nabavu in house. ${ }^{49}$

Sud je u sudskoj praksi zaključio da se pravu Unije protivi ograničavanje sudjelovanja ponuditelja ili natjecatelja prema njihovu pravnom obliku ${ }^{50} \mathrm{ili}$ vrsti vlasništva, tj. ovisno o tome tko ima kontrolu nad gospodarskim subjektom. ${ }^{51}$ Kada javnopravna tijela ne bi mogla biti gospodarski subjekti u javnoj nabavi, to bi omogućilo zaobilaženje propisa o javnoj nabavi na temelju neprofitnosti subjekta kojemu je dodijeljen posao. ${ }^{52}$

Sud je također istaknuo da to što drugi javni naručitelj izravno ne izvršava ugovor nego angažira podizvođače koje odabire na temelju postupka javne nabave ne izuzima ugovor između prvog i drugog javnog naručitelja iz pojma "ugovor o javnoj nabavi”. ${ }^{33}$ Primjena pravila javne nabave ne može se izbjeći na temelju svojstva suugovaratelja. ${ }^{54}$ To što je drugi javni naručitelj eventualno dužan sam poslije provesti postupak javne nabave radi pronalaska izvršitelja

48 Adolf Trulley (C-373/00, EU:C:2003:110, t. 42 - 45).

49 Komisija/Španjolska (C-84/03, EU:C:2005:14, t. 38), Auroux i dr. (bilj. 2); CoNISMa (bilj. 5), Piepenbrock (bilj. 23) i Data Medical Service (bilj. 5). Vidjeti također Boesen, A., Stadtplanerische Neugestaltung als öffentlicher Bauauftrag, Europäische Zeitschrift für Wirtschaftsrecht, vol. 4, 2007., str. 121 - 123; Otting, O., Teilnahme von öffentlichen Einrichtungen an Verfahren zur Vergabe öffentlicher Aufträge, Neue Zeitschrift für Verwaltungsrecht, 2015., str. 283 - 284; Daniel, É., Organisme de droit public, Europe, br. 2, veljača 2015., str. $30-31$.

50 Frigerio Luigi \& C. (C-357/06, EU:C:2007:818, t. 22), Auroux i dr. (bilj. 2, t. 66) i CoNISMa (bilj. 5, t. 39).

${ }^{51}$ Kao što to proizlazi iz presude Komisija/Italija (C-3/88, EU:C:1989:606), u kojoj je bila riječ o ograničenju sudjelovanja u korist društava u kojima država ili javni sektor izravno ili neizravno imaju većinu ili sav temeljni kapital.

52 CoNISMa (bilj. 5, t. 43, 48, 49 i 51), Komisija/Italija (C-119/06, EU:C:2007:729, t. 41) i Azienda sanitaria locale n. 5 "Spezzino" i dr. (bilj. 40, t. 36).

53 Teckal (bilj. 44, t. 51); Auroux i dr. (bilj. 2, t. 38, 44, 47, 66 i 68); Lecce (bilj. 40, t. 26) i Piepenbrock (bilj. 23, t. 29).

54 CoNISMa (bilj. 5, t. 30 i 45) i Lecce (bilj. 40, t. 26) i Undis Servizi (bilj. 44, t. 28). 
predmeta nabave, ne oslobađa te iste dužnosti prvog naručitelja. ${ }^{55}$ Međutim, Sud je i u odnosu na tu pretpostavku razvio određene iznimke, koje će biti izložene u nastavku.

Nasuprot tomu, i to što je neki subjekt pravna osoba privatnog prava, ne isključuje ga automatski iz pojma javnog naručitelja ako ispunjava kriterije predviđene općom direktivom o javnoj nabavi jer način osnivanja tog subjekta nije relevantan za njegovu kvalifikaciju. ${ }^{56}$

\subsubsection{Nabava “in house” $i$ institucionalna suradnja javnih naručitelja}

Iznimka u pogledu nabave in house jedna je od najranijih i najvažnijih koje je Sud razvio u vezi sa suradnjom javnih tijela. Na temelju te iznimke razvile su se zatim još dvije iznimke u pogledu njihove ugovorne suradnje i prijenosa nadležnosti između javnih tijela, koje će se analizirati kasnije u tekstu, s obzirom na to da prva iznimka nije mogla pokriti sve pojavne oblike javno-javne suradnje.

Iznimka in house "temelji [se] na pristupu prema kojem se može smatrati da [javni] naručitelj u takvom slučaju poseže za vlastitim resursima radi obavljanja svojih zadaća u javnom interesu". ${ }^{57}$ Drugim riječima, ako u konkretnom slučaju nema odnosa između dviju pravno različitih osoba, primjerice ako se javni naručitelj koristi svojim unutarnjim poslovnim jedinicama ${ }^{58}$, nije ostvareno četvrto obilježje ugovora o javnoj nabavi.

Međutim, Sud je u praksi otišao korak dalje te je pod određenim pretpostavkama primjenu te iznimke proširio i na slučaj u kojem je u stvarnosti riječ o dvjema pravno različitim osobama, ali je njihov međusobni odnos takav da se on može izjednačiti s pravom internom ili kućnom nabavom. Neki autori

55 Auroux i dr. (bilj. 2, t. 66 i 68); Boesen, A., op. cit. u bilj. 49, str. 121; Wagner, O.; Görs, B., Ausschreibungspflichtigkeit von Investorenwettbewerben, Neue Zeitschrift für Verwaltungsrecht, vol. 8, 2007., str. $900-902$.

56 Komisija/Španjolska (C-214/00, EU:C:2003:276, t. 52-56) i Komisija/Španjolska (bilj. 49, t. $27-32$ ).

57 Centro Hospitalar de Setúbal i SUCH (C-574/12, EU:C:2014:2004, t. 35, dalje u tekstu: SUCH).

58 Sud je jasno izrazio stajalište prema kojem svako javno tijelo koje je ujedno javni naručitelj smije obavljati zadaće koje su mu povjerene u javnom interesu koristeći se pritom vlastitim administrativnim, tehničkim i drugim resursima, bez ikakve obveze angažiranja vanjskih subjekata koji nisu dio njegovih službi (Stadt Halle (bilj. 45, t. 48.); Wiggen, J., op. cit. u bilj. 9, str. 159). 
zbog toga razlikuju pravu i kvazi nabavu in house $e^{59}$, ali s obzirom na to da Sud EU-a u svojoj praksi i u potonjem slučaju govori o nabavi in house, isti je pristup primijenjen i u ovom radu.

Riječ je zapravo o specifičnom obliku statusnopravne javno-javne suradnje koji se odnosi na vertikalnu suradnju jednog ili više javnih naručitelja i njihovih društava kćeri. U tom kontekstu Sud je zaključio da iznimka od četvrtog obilježja postoji samo ako (i) javni naručitelj nad kontroliranim subjektom obavlja nadzor sličan nadzoru koji obavlja nad vlastitim službama i (ii) ako istodobno taj subjekt bitan dio svoje djelatnosti obavlja za jednog ili nekoliko javnih naručitelja koji u njemu imaju udjele (tj. koji ga kontroliraju). ${ }^{60}$

Što se tiče učinka navedene proširene iznimke, isprva nije bilo jasno je li i u tom slučaju riječ o nepostojanju ugovora o javnoj nabavi zbog nedostatka njegova četvrtog bitnog obilježja ${ }^{61}$ ili je samo riječ o fikciji koja za posljedicu ima samo iznimku od obveze provođenja postupka javne nabave. ${ }^{62} \mathrm{~S}$ tim u vezi Sud je s jedne strane u presudi Stadt Halle utvrdio da je riječ o iznimci koja se primjenjuje iako su javni naručitelj i njegov suugovaratelj u pravnom smislu različite osobe, što bi bilo bliže shvaćanju da postoji ugovorni odnos. ${ }^{63} \mathrm{~S}$ druge strane, Sud je u presudi Asemfo u pogledu alternativne primjene sudske prakse Teckal utvrdio da se kontrolirani subjekt ne može smatrati trećom osobom u odnosu na teritorijalne jedinice koje drže udjele u njegovu temeljnom kapitalu, što bi bilo bliže stajalištu o nepostojanju ugovornog odnosa ${ }^{64}$, a tako bi se moglo zaključiti i iz same presude Teckal, u kojoj Sud nastavno na postavljeno pravilo o postojanju ugovora između dviju različitih osoba utvrdio da "[d]rukčije može biti samo ako [...]" su ispunjene dvije navedene pretpostavke. Ipak, u novijoj sudskoj praksi Sud više naglašava da je to samo iznimka od obveze provođenja postupka javne nabave, pa je vjerojatno samo bila riječ o prolaznoj neusklađenosti sudske prakse. ${ }^{65} \mathrm{U}$ svakom slučaju, sada iz članka 12 . stavka 1 .

59 Wiggen, J., op. cit. u bilj. 9, str. 159.

60 Teckal (bilj. 44, t. 50) kao i SUCH (bilj. 57, t. 12) i Undis Servizi (bilj. 44, t. 6).

${ }^{61} \mathrm{U}$ tom smislu vidjeti Rabolt, K., Die so genannte Inhouse-Beziehung zwischen Gebietskörperschaft und Dienstleistungsersteller als Ausnahme vom Ausschreibungswettbewerb, u: Cox, H. (ur.), Ausschreibungswettbewerb bei öffentlichen Dienstleistungen, Nomos, Baden-Baden, 2003., str. 110.

62 U tom smislu vidjeti Bernal Blay, M. A., Un paso en falso en la interpretación del criterio del control análogo al de los propios servicios en las relaciones in house, Revista española de Derecho Administrativo, br. 137, 2008., str. 118 i 123.

63 Stadt Halle (bilj. 45, t. 49 i 50).

64 Asemfo (bilj. 12, t. 61).

65 SUCH (bilj. 57, t. 12), Datenlotsen (bilj. 45, t. 25) i Undis Servizi (bilj. 44, t. 6 i 30). 
opće direktive o javnoj nabavi očito proizlazi da iznimka in house ne dovodi u pitanje kvalifikaciju ugovora o javnoj nabavi, nego ga samo izuzima iz područja primjene te direktive. ${ }^{66}$

Usto, navedena je iznimka od četvrtog obilježja ugovora o javnoj nabavi kodifikacijom proširena i na još dva oblika institucionalne suradnje javnih naručitelja: (i) obrnute vertikalne odnose kontroliranog subjekta i njegova osnivača i (ii) horizontalne poslove in house između kontroliranih subjekata istog osnivača, o čemu će više biti riječi u nastavku.

\section{(a) Kriterij nadzora ili kontrole}

Što se tiče prve pretpostavke obavljanja sličnog nadzora kao nad vlastitim službama, treba uzeti u obzir sve mjerodavne zakonske odredbe i konkretne okolnosti. ${ }^{67}$ Prije svega, mora biti riječ o mogućnosti presudnog utjecaja na strateške ciljeve i važne odluke konkretnog subjekta i taj nadzor mora biti učinkovit, strukturan i funkcionalan. ${ }^{68}$ Okolnosti koje Sud pritom razmatra obuhvaćaju sljedeća pitanja: (i) tko su članovi kontroliranog subjekta, odnosno tko sudjeluje u njegovu temeljnom kapitalu, (ii) sastav njegovih organa i (iii) opseg ovlasti uprave. ${ }^{69}$

\section{(i) Članovi kontroliranog subjekta}

Kao prvo, ako javni naručitelj sam ili zajedno $s$ drugim javnim tijelima ${ }^{70}$ drži sve udjele u temeljnom kapitalu kontroliranog subjekta, Sud je naglasio da

66 "Ugovor o javnoj nabavi koji javni naručitelj dodijeli drugoj pravnoj osobi [...] privatnog ili javnog prava ne spada u područje primjene ove Direktive ako su ispunjeni svi sljedeći uvjeti [...]" Namjerno je izostavljena očito pogrešna formulacija "na temelju privatnog ili javnog prava".

67 Carbotermo i Consorzio Alisei (C-340/04, EU:C:2006:308, t. 36, dalje u tekstu: Carbotermo).

68 Parking Brixen (bilj. 45, t. 65); Carbotermo (bilj. 70, t. 36); Coditel Brabant (C324/07, EU:C:2008:621, t. 28); Econord (C182/11 i C183/11, EU:C:2012:758, t. 27) i Datenlotsen (bilj. 45, t. 25). Ta je sudska praksa sada kodificirana člankom 12. stavkom 1. drugim podstavkom opće direktive o javnoj nabavi.

69 Coditel Brabant (bilj. 68, t. 34). Slični su kriteriji predviđeni sada i u članku 12. stavku 3. drugom podstavku opće direktive o javnoj nabavi, iako samo u odnosu na statusnopravnu suradnji nekoliko javnih tijela.

70 Stajalište je Suda da sličan nadzor kao nad vlastitim službama može ostvarivati i nekoliko javnih naručitelja zajedno (Carbotermo (u bilj. 67, t. 37 i 69); Asemfo (bilj. 12, t. 57 i 65) i Coditel Brabant (u bilj. 68, t. 49)). Mogućnost obavljanja zajedničkog nadzora sada je također izričito predviđena člankom 12. stavkom 3. opće direktive o javnoj nabavi. 
to upućuje na zaključak da on ili oni ostvaruju sličan nadzor kao nad vlastitim službama. ${ }^{71}$ Pritom za ocjenu obavljanja takvog nadzora nije relevantna veličina udjela u temeljnom kapitalu. Može biti riječ o sasvim malom udjelu, kao što je to bio slučaj u presudama Asemfo i Coditel Brabant. ${ }^{72}$ Sud je, međutim, isključio svaku mogućnost sudjelovanja privatnog kapitala u temeljnom kapitalu pravne osobe kojoj javni naručitelj namjerava izravno povjeriti određen predmet nabave $^{73}$, što je obrazložio time da se privatni subjekti vode načelima koja su svojstvena njihovim privatnim interesima, a oni se po svojoj naravi razlikuju od ciljeva u javnom interesu koje želi ostvariti javni naručitelj ${ }^{74}$, i da bi time privatni investitori ostvarili prednost $\mathrm{u}$ odnosu na svoje konkurente. ${ }^{75}$

Sada je člankom 12. stavkom 1. prvim podstavkom točkom (c) opće direktive o javnoj nabavi zabranjeno samo izravno sudjelovanje privatnog kapitala. Dopušteno je, dakle, neizravno sudjelovanje tog kapitala ${ }^{76}$, a istom je odredbom predviđena i posebna iznimka u pogledu sudjelovanja privatnog kapitala koje nema značajke kontroliranja i blokiranja ${ }^{77}$ i ne vrši odlučujući utjecaj na pravnu

71 Carbotermo (bilj. 70, t. 37); Asemfo (bilj. 12, t. 57) i Coditel Brabant (bilj. 68, t. 31).

72 Asemfo (bilj. 12, t. 58 i 59), gdje je bila riječ o udjelima od 0,25 \% temeljnog kapitala, i Coditel Brabant (bilj. 68, t. 50).

73 Sud je to u presudi Stadt Halle (bilj. 45, t. 49) izrazio riječima: “[Č]ak i manjinsko sudjelovanje privatnog poduzetnika u temeljnom kapitalu društva u kojem sudjeluje i javni naručitelj u svakom slučaju isključuje postojanje takvog nadzora.”; Krohn, M., Neues zu den Public Private Partnerships: In-house-Vergaben und Rechtsschutz gegen De-facto-Vergaben, European Law Reporter, br. 1, 2005., str. 19 - 23. Vidjeti i presudu Coname (C-231/03, EU:C:2005:487, t. 26). Sud je u presudi SUCH (bilj. 57) potvrdio usko tumačenje te iznimke pa je zaključio da i sudjelovanje privatnopravnih organizacija iz neprofitnog sektora isključuje njezinu primjenu, Probst, P. M., Gemeinnützigkeit schützt nicht vor Vergabepflicht!, European Law Reporter, br. 3, 2014., str. 103 - 105, i Clarke, C. M., The CJEU's Evolving Interpretation of In-House Arrangements under the EU Public Procurement Rules: A Functional or Formal Approach?, European Procurement \& Public Private Partnership Law Review, vol. 10, br. 2, 2015., str. 120 - 121. Stadt Halle (bilj. 45, t. 50) i SUCH (bilj. 57, t. 36). Stadt Halle (bilj. 45, t. 51).

76 Primjerice, ako u strukturi kapitala pravne osobe (javnog naručitelja) koja kontrolira drugi subjekt sudjeluje privatni kapital.

77 Uzimajući u obzir odredbe članka 301. i 455. Zakona o trgovačkim društvima (Narodne novine, br. 111/1993, 34/1999, 121/1999, 52/2000, 118/2003, 107/2007, 146/2008, 137/2009, 125/2011, 152/2011, 111/2012, 68/2013, 110/2015), to bi u kontekstu hrvatskog prava za dionička društva i društva s ograničenom odgovornošću značilo manjinsko sudjelovanje do 24,99 \% temeljnog kapitala, osim ako statutom ili društvenim ugovorom nije predviđena veća potrebna većina, u kojem bi slučaju i takvo sudjelovanje moralo biti razmjerno manje. Za dionička društ- 
osobu pod kontrolom, a propisano je nacionalnim zakonodavnim odredbama, pod uvjetom da je u skladu s UFEU-om. ${ }^{78}$

Što se tiče ograničenja u pogledu sudjelovanja privatnog kapitala, apsolutno su zabranjene naknadne promjene strukture dioničara ili članova kontroliranog društva kojima bi se nakon interne dodjele ugovora kontrola prenijela na privatne investitore, što bi prema stajalištu Suda činilo zabranjenu izravnu dodjelu ugovora. ${ }^{79}$ Nasuprot tomu, Sud je ocijenio da sama mogućnost sudjelovanja privatnog kapitala predviđena $\mathrm{u}$ temeljnim aktima kontroliranog subjekta $\mathrm{u}$ trenutku dodjele ugovora o javnoj nabavi ne oduzima automatski tom odnosu kvalifikaciju nabave in house, nego je za to potrebno utvrditi stvarne izglede da će ubrzo nakon dodjele ugovora u člansku strukturu kontroliranog subjekta ući privatni kapital. ${ }^{80}$

Treba naglasiti da je člankom 12. stavkom 1. drugim podstavkom opće direktive ${ }^{81}$ o javnoj nabavi, kojim se određuje da javni naručitelj nad pravnom osobom provodi kontrolu sličnu onoj koju provodi nad svojim poslovnim jedinicama ako ima presudan utjecaj na strateške ciljeve i na važne odluke pravne osobe nad kojom se provodi kontrola, omogućeno proširenje primjene iznimke in house i na odnose holding društva s društvima unukama iako je Sud prije u presudi Carbotermo utvrdio da neizravno sudjelovanje javnog naručitelja u kapitalu ugovaratelja putem holding društva umanjuje mogućnost takvog nadzora kao nad vlastitim službama. ${ }^{82}$

va jednak zaključak može se izvesti i na temelju odredbe članka 9. stavka 1. Zakona o preuzimanju dioničkih društava (Narodne novine, br. 109/2007, 36/2009, 108/2012, 90/2013, 99/2013, 148/2013), kojim je predviđen prag od 25 \% dionica s pravom glasa kao okidač za obveznu ponudu za preuzimanje.

78 Janssen, W. A., op. cit. u bilj. 15, str. $174-176$.

79 Komisija/Austrija (C-29/04, EU:C:2005:670, t. 38 - 42) i ANAV (bilj. 45, t. 30 - 32); Frenz, W., Ausschreibungspflicht bei Anteilsveräußerungen und Enkelgesellschaften, Neue juristische Wochenschrift, vol. 37, 2006., str. 2666.

80 Sea (C-573/07, EU:C:2009:532, t. 50 i 51). Iz toga je vidljivo da je Sud skloniji kazuističkoj analizi svakog slučaja koja uzima u obzir ekonomsku realnost, a ne formalnu (ne)usklađenost. Sud je u presudi Sea (t. 47 i 48) utvrdio da su takvi ozbiljni izgledi postojali u predmetima Parking Brixen (bilj. 45, t. 67 i 72), u kojima je nacionalno zakonodavstvo propisivalo obvezan ulazak privatnog kapitala ubrzo nakon dodjele, i Komisija/Austrija (bilj. 79, t. 38 - 42), u kojem je bila riječ o umjetnoj konstrukciji stvorenoj radi zaobilaženja pravila Unije o javnoj nabavi.

81 “Takvu kontrolu također može provoditi i drugi subjekt nad kojim javni naručitelj ili naručitelj na isti način provodi kontrolu."

82 Carbotermo (bilj. 67, t. 39). Vidjeti također Janssen, W. A., op. cit. u bilj. 15, str. 176, i Frenz, W., op. cit. u bilj. 79, str. 2667. 
Člankom 12. stavkom 2. te direktive ${ }^{83}$ primjena iznimke in house proširena je i na obrnute vertikalne odnose nabave u kojima kontrolirani subjekt dodjeljuje ugovor o javnoj nabavi svojem osnivaču. Time je popunjena pravna praznina u pogledu tog oblika suradnje javnih naručitelja jer Sud, da je i imao tu priliku, ne bi mogao proširiti primjenu iznimke in house na takav obrnuti odnos, s obzirom na to da kontrolirani subjekt po prirodi stvari ne bi mogao ispuniti nijedan od dvaju kriterija Teckal u odnosu prema svojem osnivaču. ${ }^{84}$

$\mathrm{U}$ pogledu horizontalnih poslova in house između dvaju gospodarskih subjekata nad kojima nadzor ostvaruje isti javni naručitelj, Sud je u predmetu Datenlotsen imao priliku razmatrati mogućnost izuzeća od primjene pravila o javnoj nabavi, ali nije konačno odlučio je li takva praksa u skladu sa sudskom praksom Teckal jer u konkretnom slučaju, prema mišljenju Suda, javni naručitelj nije ostvarivao takav nadzor nad jednim od tih gospodarskih subjekata. ${ }^{85}$

Međutim, također u skladu s člankom 12. stavkom 2. opće direktive o javnoj nabavi, primjena iznimke in house može se primijeniti i na dodjele poslova između kontrolirane pravne osobe i druge pravne osobe "nad kojom isti javni naručitelj provodi kontrolu". 86

Obje kodifikacije treba pozdraviti zbog dodatne pravne sigurnosti. Treba napomenuti da i dalje nije izričito regulirano pitanje primjene iznimke in house na horizontalne i obrnute vertikalne odnose nabave u slučaju subjekta nad kojim nadzor obavlja nekoliko istih javnih naručitelja, pa će i to pitanje dobiti odgovor tek u budućoj sudskoj praksi. ${ }^{87}$

\section{(ii) Sastav organa kontroliranog subjekta}

Kao drugo, u pogledu sastava korporativnih organa, u skladu sa sudskom praksom u njima moraju sudjelovati predstavnici javnih naručitelja koji drže

83 "Stavak 1. se također primjenjuje ako pravna osoba pod kontrolom koja je javni naručitelj dodijeli ugovor svojem javnom naručitelju koji nad njim provodi kontrolu $[\ldots] "$

84 Janssen, W. A., op. cit. u bilj. 15, str. 177.

85 Datenlotsen (bilj. 65, t. 28 - 33); Falle, J., Hamburg again: shared services and public sector cooperation in the case of Technische Universitat Hamburg-Harburg v Datenlotsen Informationssysteme GmbH, Public Procurement Law Review, br. 5, 2014., str. NA127.

86 Janssen, W. A., op. cit. u bilj. 15, str. 177; Meister, M., Qualification du contrat "in house", Europe, br. 7, srpanj 2014., str. $27-28$.

87 Primjerice, treba vidjeti kako će Sud primijeniti nove odredbe na situacije poput one u predmetu Datenlotsen (bilj. 45 i 109). Nije jasno je li takav odnos u skladu s novim odredbama ili se nove iznimke primjenjuju samo kada kontrolirani subjekti imaju potpuno iste osnivače. Vidjeti Falle, J. op. cit. u bilj. 85, str. NA127 - NA130. 
udjele u njegovu kapitalu i koji na taj način mogu presudno utjecati na njegove strateške ciljeve i važne odluke. ${ }^{88}$ To je sada precizirano i u članku 12. stavku 3. drugom podstavku točki i. opće direktive o javnoj nabavi, s dodatkom da “[p]ojedinačni predstavnici mogu predstavljati nekoliko sudjelujućih javnih naručitelja ili sve njih."

\section{(iii) Opseg ovlasti uprave kontroliranog subjekta}

Kao treće, što se tiče opsega ovlasti uprave, može se zaključiti da prva pretpostavka nadzora nije ispunjena ako uprava kontroliranog društva ima široke ovlasti. U tom je pogledu Sud u predmetu Carbotermo utvrdio da javni naručitelj ne ostvaruje takav nadzor ako su njegove ovlasti ograničene na mogućnosti koje na raspolaganju ima kao većinski član društva u skladu s pravom društava, to jest ako nema posebna prava kojima može ograničiti slobodu djelovanja uprave. ${ }^{89}$

Iako je Sud u presudi Coditel Brabant naizgled zauzeo suprotno stajalište prema kojem, unatoč širokim ovlastima uprave zajedničkog društva koncesionara, općine koje su sudjelovale u temeljnom kapitalu tog društva ostvaruju sličan nadzor kao nad vlastitim službama i taj nadzor mogu ostvarivati zajedno donoseći odluke običnom većinom ${ }^{90}$, u tom je slučaju ponajprije bila riječ o međusobnom odnosu članova i ostvarivanju zajedničke kontrole, pa treba zaključiti da ono ne odstupa od prethodnog stajališta Suda iz presude Carbotermo u pogledu posebnih prava koja članovi kontroliranog subjekta moraju imati u odnosu prema njegovoj upravi.

Nadalje, u presudi Econord Sud je u pogledu odnosa članova kontroliranog subjekta također pojasnio da se, iako nije nužno da kontrolu obavljaju pojedinačno, ta kontrola ne smije oslanjati isključivo na ovlasti nadzora većinskog člana. ${ }^{91}$ Ako neki član nema ni najmanju mogućnost sudjelovanja u kontroli

88 Coditel Brabant (bilj. 68, t. 29).

89 Carbotermo (bilj. 67, t. $37-40)$.

90 Coditel Brabant (bilj. 68, t. 33 - 41 i 54) i Komisija/Njemačka (C-480/06, EU:C:2009:357, t. 35). Presudom Coditel Brabant do krajnjih je granica rastegnuta primjena iznimke in house na institucionalne oblike suradnje javnih naručitelja, što je u konačnici moralo dovesti do stvaranja posebne iznimke u pogledu ugovorne suradnje javnih naručitelja; vidjeti Pedersen, K.; Olsson, E., Commission v Germany - a new approach to in-house providing?, Public Procurement Law Review, br. 1, 2010., str. 33 - 45, i Broussy, E.; Donnat, F.; Lambert, C., Marchés - In house et coopération intercommunale, Lactualité juridique: droit administratif, br. 42, 2008., str. 2336 - 2337.

91 Econord (C182/11 i C183/11, EU:C:2012:758, t. 30); Mužina, A., Razjasnitev uporabe notranjih (in-house) razmerij pri izvajanju javnih naročil/koncesij, Pravna praksa, br. 48, 2012., str. $21-22$. 
tog subjekta, to bi otvorilo mogućnost zaobilaženju pravila o javnoj nabavi jer bi samim članstvom u tom subjektu svako javno tijelo bilo izuzeto od obveze provođenja postupka javne nabave u korist tog subjekta. ${ }^{92}$

\section{(b) Kriterij djelatnosti}

Što se tiče druge pretpostavke obavljanja bitnog dijela svoje djelatnosti za javnog naručitelja, u skladu s ustaljenom sudskom praksom, poslovanje kontroliranog subjekta mora ponajprije biti namijenjeno javnom tijelu ili javnim tijelima koji ga kontroliraju, a svaka druga djelatnost mora biti isključivo sporedne naravi. ${ }^{93}$ Prilikom utvrđivanja te pretpostavke uzimaju se u obzir sve kvalitativne i kvantitativne okolnosti, poput prihoda ostvarenog s javnim naručiteljem koji vrši nadzor, uključujući i prihod od korisnika usluga. ${ }^{94}$

Ako je riječ o nekoliko javnih tijela koja ostvaruju zajednički nadzor, kontrolirani subjekt ne mora obavljati glavninu svojih djelatnosti sa svakim pojedinim javnim tijelom, nego je dovoljno da je taj kriterij općenito ispunjen u odnosu na sva javna tijela koja u njemu imaju udjele. ${ }^{95}$

Prilikom ocjene tog kriterija Sud je izričito isključio mogućnost uzimanja u obzir poslova koje kontrolirani subjekt pruža drugim javnim tijelima koja nisu njegovi članovi.$^{96}$ Pritom nije relevantno da je do dodjele poslova u korist drugih javnih tijela došlo naredbom drugog javnog tijela koje nije član kontroliranog subjekta, ali je nadređeno njegovim članovima. ${ }^{97}$

92 Ibid., t. 31. Hamerl, T., In-house-Vergabe bei gemeinsamer Kontrolle über den Auftragnehmer, Zeitschrift für Vergaberecht und Beschaffungspraxis, vol. 3, 2013., str. 123.

93 Teckal (bilj. 44, t. 50); SUCH (bilj. 57, t. 12), Carbotermo (bilj. 67, t. 63 i 65) i Undis Servizi (bilj. 44, t. 31 i 32). Drugim riječima, kako je to Sud izrazio u presudi Parking Brixen (bilj. 45, t. 67), kontrolirani subjekt ne smije biti tržišno orijentiran, što se može vidjeti i prema tome je li djelatnost koju obavlja ograničena na geografsko područje javnog tijela ili teritorijalne jedinice (Steinberg, P., Öffentlicher Auftraggeber als Mehrheitsaktionär des Auftragnehmers, Europäische Zeitschrift für Wirtschaftsrecht, vol. 12, 2006., str. 380).

94 Carbotermo (bilj. 67, t. 64 - 67) i Undis Servizi (bilj. 44, t. 32).

95 Carbotermo (bilj. 67, t. 70) i Asemfo (bilj. 12, t. 62).

96 Carbotermo (bilj. 67, t. 60) i Undis Servizi (bilj. 44, t. 33).

97 Undis Servizi (bilj. 44, t. 37). Zanimljivo je primijetiti da se unatoč tomu što je bila riječ o javnopravnom aktu ovdje nije postavilo pitanje postojanja prvog obilježja, tj. ugovornog odnosa, kao što je bio slučaju u presudama Asemfo i Correos. Opravdano se može postaviti pitanje je li onda i za primjenu iznimke nepostojanja ugovornog odnosa potreban odnos kontrole kao u slučaju iznimke in house. 
Zakonodavac je to sada u navedenom članku 12. stavku 1. prvom podstavku točki (b) odnosno članku 12. stavku 3. prvom podstavku točki (b) konkretizirao postotkom od $80 \%$ tako da će se iznimka in house primjenjivati i na pravne osobe koje nešto manje od 20 \% svojih aktivnosti obavljaju za druga javna tijela ili na tržištu. ${ }^{98}$ Usto je člankom 12. stavkom 5. opće direktive o javnoj nabavi predviđeno da se uzima u obzir "prosjek sveukupnog prometa ili odgovarajuće alternativno mjerilo koje se temelji na djelatnosti, poput troškova koje su relevantna pravna osoba ili javni naručitelj imali za usluge, robu i radove za razdoblje od tri godine prije dodjele ugovora" ili u nedostatku takvih podataka "dostatno je da ta pravna osoba poslovnim projekcijama pokaže da je mjerilo djelatnosti vjerodostojno”.

\subsubsection{Ugovorna suradnja javnih naručitelja}

Kao što je prije navedeno, Sud je iznimku nabave in house najprije primijenio na vertikalnu institucionalnu suradnju javnih naručitelja sa subjektima koje kontroliraju u smislu kriterija sudske prakse Teckal. Međutim, to je ostavilo po strani različite oblike javnopravne ugovorne suradnje javnih tijela koji nužno ne podrazumijevaju osnivanje novog zajednički kontroliranog subjekta koji bi ispunjavao kriterije Teckal, a u praksi su potrebni radi boljeg izvršavanja javnih zadaća u općem interesu. ${ }^{99}$ Zbog toga Sud u prvom takvom slučaju nije oklijevao odbiti Komisijino stajalište da se suradnja javnih naručitelja može ostvarivati samo osnivanjem posebnog subjekta, čime je uspostavio novu, posebnu iznimku u pogledu ugovorne suradnje javnih naručitelja. ${ }^{100}$

U skladu s navedenom sudskom praksom, pravila prava Unije o javnoj nabavi nisu primjenjiva na (i) ugovore o suradnji javnih tijela radi osiguranja provedbe

98 Janssen, W. A., op. cit. u bilj. 15, str. 176. Sud se već u presudi Asemfo (bilj. 12, t. 63) osvrnuo na konkretne postotke djelatnosti koju kontrolirani subjekt obavlja u korist svojih osnivača. Ipak, u tom je slučaju bila riječ o 90 \% djelatnosti, što pokazuje dodatnu želju zakonodavca za ublažavanjem tog kriterija.

99 U hrvatskom pravu mogućnost statusnopravne i ugovorne suradnje lokalnih tijela predviđena je člankom 54. Zakona o lokalnoj i područnoj (regionalnoj) samoupravi (Narodne novine, br. 33/2001, 60/2001, 129/2005, 109/2007, 125/2008, 36/2009, 36/2009, 150/2011, 144/2012, 19/2013, 137/2015).

${ }^{100}$ Komisija/Njemačka (bilj. 90, t. 37 i 47) i Lecce (bilj. 40, t. 31 i 34) i mišljenje nezavisne odvjetnice V. Trstenjak u potonjem predmetu (C-159/11, EU:C:2012:303, t. 65). U dijelu je teorije sporno je li riječ o posebnoj iznimci ili o nastavku sudske prakse Teckal. Vidi Janssen, W. A., op. cit. u bilj. 15, str. 177, i Pedersen, K.; Olsson, E., op. cit. u bilj. 90, str. 44. 
zadaće javne službe (ii) koja im je zajednička ${ }^{101}$, pod dodatnim uvjetom (iii) da su takvi ugovori sklopljeni samo između javnih tijela, odnosno bez sudjelovanja privatnopravnih subjekata ${ }^{102}$, (iii) da nijedan privatnopravni pružatelj usluga nije stavljen u povlašten položaj u odnosu na svoje konkurente ${ }^{103} \mathrm{i}$ (iv) da se suradnja koju uspostavljaju vodi isključivo razmatranjima i zahtjevima svojstvenima težnji za ostvarenjem ciljeva u javnom interesu. ${ }^{104}$ Pritom treba imati na umu da je riječ o kumulativnim pretpostavkama. ${ }^{105}$

Treba naglasiti da je u tom slučaju zapravo riječ o iznimci u pogledu pripremnih radnji javnih naručitelja koji zajedno namjeravaju organizirati postupak javne nabave radi provedbe projekta od zajedničke važnosti, što može podrazumijevati i dogovore u pogledu snošenja troškova realizacije projekta i kasnijeg poslovanja. ${ }^{106}$ Nijedna od ugovornih strana nije izvršitelj posla za račun svih uključenih javnih tijela, pa se ta iznimka u tom pogledu razlikuje od situacija u kojima je drugi javni naručitelj zapravo preuzeo izvršenje posla za drugog javnog naručitelja uz naknadu. ${ }^{107} \mathrm{U}$ tom smislu takvom odnosu nedostaje element naplatnosti. ${ }^{108}$

101 Drugim riječima, nije dovoljno da jedno tijelo drugom pruža usluge koje se mogu kvalificirati kao javna služba, nego mora biti riječ o osiguravanju provedbe zadaće javne služba koja im je zajednička. Vidjeti u tom smislu presude Lecce (bilj. 40, t. 37), Piepenbrock (bilj. 23, t. 39 i 40) i Datenlotsen (bilj. 45, t. 35). Vidjeti također Durviaux, A. L., La coopération horizontale, Revue trimestrielle de droit européen, br. 2, 2013., str. 346, i Hojnik, J., Sporazumi med javnimi subjekti v luči pravil EU o javnem naročanju, Davčno-finančna praksa: davki, finance, zavarovalništvo, br. 2, 2013., str. $25-28$.

${ }^{102}$ Ovdje je riječ o identičnom kriteriju kao u ranijoj sudskoj praksi u pogledu nabave in house.

103 Ovdje je riječ o zabrani pogodovanja kojim nekom poduzetniku može nastati određena prednost. Riječ je o kriteriju koji je Sud u presudi Komisija/Njemačka (bilj. 90, t. 47) preuzeo iz presude Stadt Halle (bilj. 45, t. 51). U presudi Lecce (bilj. 40, t. 40) Sud je zaključio da poduzetnici koji surađuju s jednim o dvaju javnih tijela koja su sklopila ugovor o suradnji mogu biti dovedeni u položaj prednosti u odnosu prema drugim poduzetnicima aktivnim na istom tržištu. Zato se u tom dijelu i dalje primjenjuju pravila o javnoj nabavi.

104 Komisija/Njemačka (bilj. 90, t. 47); Lecce (bilj. 40, t. 34 i 35); Piepenbrock (bilj. 23 , t. 36 - 38) i Datenlotsen (bilj. 45, t. 34 i 35). Za iscrpnu analizu vidi Pedersen, K.; Olsson, E., op. cit. u bilj. 90, str. 33 - 45, i Azienda: the creation of an exemption from public procurement law, Public Procurement Law Review, br. 6, 2013., str. 225 - 235.

105 Lecce (bilj. 40, t. 36) i Piepenbrock (bilj. 23, t. 38).

$106 \mathrm{U}$ tom smislu vidi Wiggen, J., op. cit. u bilj. 9, str. 162 - 163.

107 Primjerice predmeti Auroux i Piepenbrock, vidi bilj. 53 i tekst iznad bilješke.

108 Wiggen, J., op. cit. u bilj. 9, str. 162, i Janssen, W. A., op. cit. u bilj. 15, str. 178. 
Iznimka ugovorne suradnje kodificirana je člankom 12. stavkom 4. opće direktive o javnoj nabavi. Kako se može primijetiti, kodifikacija je sudsku praksu izmijenila u pogledu druge pretpostavke prema kojoj mora biti riječ o javnoj službi koja je zajednička javnim tijelima koja ugovaraju suradnju. Direktiva sada naglasak stavlja na ostvarivanje zajedničkih ciljeva, iako i dalje prva svrha suradnje mora biti obavljanje javnih službi (“javnih usluga”) koje su u njihovoj nadležnosti. Čini se da se tom izmjenom željelo omogućiti suradnju javnih tijela koja imaju različite javne zadaće, dok je u sudskoj praksi naglasak bio na obavljanju iste javne službe. ${ }^{109}$

Također, iz uvodne izjave 32. opće direktive o javnoj nabavi proizlazi da je namjera zakonodavca Unije bila odstupiti od stroge zabrane sudjelovanja privatnog kapitala, pa je mogućnost primjene ove iznimke proširena i na javne naručitelje koji nisu u potpuno javnom vlasništvu. ${ }^{110}$

Međutim, kodifikacijom je dodana i pretpostavka koja dosad nije bila izražena u sudskoj praksi o ugovornoj suradnji javnih tijela, prema kojoj javni naručitelji sudjelujući na otvorenom tržištu moraju ostvarivati manje od $20 \%$ aktivnosti na koje se odnosi suradnja. Time se zapravo uspostavlja ravnoteža između, s jedne strane, navedenog proširenja mogućnosti suradnje javnih tijela i, s druge strane, opasnosti od narušavanja tržišnog natjecanja. ${ }^{111}$

\subsubsection{Prijenos nadležnosti između javnih naručitelja}

Prijenos nadležnosti ili ovlasti između javnih naručitelja naizgled je sličan iznimkama u pogledu nabave in house i ugovorne suradnje javnih tijela, ali riječ je o posebnoj iznimci koja obuhvaća slučajeve preustroja javnih tijela ili stvaranja njihova novog zajedničkog subjekta. ${ }^{112}$

109 Tako je u presudi Datenlotsen (bilj. 45, t. 35) Sud zaključio da tu pretpostavku ne ispunjava suradnja Technische Universität Hamburg-Harburg i društva Hochschul-Informations-System GmbH (HIS). Iako su obje osobe iz javnog sektora (osnivač sveučilišta je savezna zemlja Freie und Hansestadt Hamburg, a osnivači i članovi HIS-a su u jednoj trećini Savezna Republika Njemačka i u dvije trećine 16 saveznih zemalja) i obavljaju komplementarne djelatnosti (obrazovanje odnosno razvoj informatičkih sustava za obrazovne ustanove iz javnog sektora), Sud je zaključio da nije riječ o obavljanju zajedničke zadaće javne službe (Falle, J. op. cit. u bilj. 85, str. NA130 - NA131).

${ }^{110}$ Janssen, W. A., op. cit. u bilj. 15, str. 179.

111 Riječ je o zahtjevu koji je u zakonodavnom postupku dodalo Vijeće, vidjeti Pedersen, K.; Olsson, E., op. cit. u bilj. 104, str. 234.

112 To je rezultat novije sudske prakse koja se počela razvijati od presude Piepenbrock (bilj. 23), a pojašnjena je nedavnom presudom Remondis (bilj. 24). 
S jedne strane, u presudi Piepenbrock Sud je, u skladu s načelom uskog tumačenja iznimki, prijenos odgovornosti za čišćenje ureda, administrativnih i školskih zgrada na drugi javnopravni subjekt uz financijsku naknadu kvalificirao kao ugovor o javnoj nabavi, zbog čega je bilo potrebno provesti postupak javne nabave, bez obzira što je prema nacionalnom pravu bila riječ o posebnom javnopravnom ugovoru između dviju teritorijalnih jedinica, odnosno javnih naručitelja. ${ }^{113}$

S druge strane, u presudi Remondis ${ }^{114}$, Sud je pak zaključio da pravni akt kojim se stvara novo javnopravno tijelo ("udruženje posebne namjene") i organizira prijenos ovlasti i odgovornosti za izvršavanje javnih zadaća nije ugovor o javnoj nabavi. Sud je naveo da "prijenos nadležnosti koji se odnosi na izvršavanje javnih zadaća postoji samo ako se istodobno odnosi na odgovornosti povezane s prenesenom nadležnosti i odgovarajuće ovlasti tako da je javno tijelo kojem se prenosi nadležnost neovisno financijski i u donošenju odluka". ${ }^{115}$ Ključan je, dakle, element te iznimke prijenos ovlasti i odgovornosti za izvršavanje konkretnih javnih zadaća.

U predmetu Piepenbrock to nije bio slučaj jer se "teritorijalna jedinica ograničila na to da drugoj teritorijalnoj jedinici za financijsku naknadu povjeri izvršavanje određenih materijalnih zadaća, zadržavajući pritom ovlast nadzora izvršenja". ${ }^{116}$ Drugim riječima, "prijenos nadležnosti ne može [...] postojati ako javno tijelo koje je postalo nadležno ne izvršava tu nadležnost samostalno i pod vlastitom odgovornosti". ${ }^{117}$

Sada je ta iznimka izričito predviđena i općom direktivom o javnoj nabavi u čijem članku 1. stavku 6. stoji: "Sporazumi, odluke ili drugi pravni instrumenti kojima se uređuje prijenos ovlasti i odgovornosti za izvršavanje javnih zadaća među javnim naručiteljima ili udruženjima javnih naručitelja te kojima nije predviđeno izvršavanje ugovornih obveza uz novčanu naknadu smatraju se pitanjima interne organizacije u dotičnoj državi članici te stoga [ta direktiva] ni na koji način ne utječe na njih."

Kako je iz navedene odredbe vidljivo, mogući su različiti pravni temelji za prijenos ovlasti, ali da bi se postigao pravi prijenos ovlasti (nadležnosti), bitno

113 Piepenbrock (bilj. 23).

114 Remondis (bilj. 24).

115 Ibid., t. 55.

116 Ibid., t. 50.

117 Ibid., t. 51; Dreyfus, J.-D., Une délégation de tâche de droit public est-elle soumise au droit des marchés publics?, L'actualité juridique: droit administratif, br. 30, 2013., str. 1753 - 1754; McGowan, D., Further Clarification of Permissible Public Cooperation: Piepenbrock, Public Procurement Law Review, br. 6, 2013., str. NA158 - NA160. 
je da se istodobno prenose i odgovornosti za izvršavanje javnih zadaća. Zato običan slučaj povjeravanja ili eksternalizacije zadaća jednog javnog tijela drugom takvom tijelu uz naknadu ne ispunjava taj kriterij, kao što je bio slučaj u predmetu Piepenbrock.

Budući da je riječ o sasvim novoj iznimci ${ }^{118}$, u nastavku se citiraju dodatna razmatranja Suda u pogledu njezine primjene:

"[T]akva samostalnost ne podrazumijeva da neki drugi javni subjekt ne smije izvršavati utjecaj na subjekt koji je postao nadležan. Naime, subjekt koji prenosi nadležnost može zadržati određena prava u odnosu na zadaće vezane uz tu javnu službu. Međutim, takav utjecaj načelno isključuje svako miješanje u konkretne načine izvršavanja zadaća koji su obuhvaćeni prenesenom nadležnosti." 119

"Samostalno djelovanje ne podrazumijeva ni to da dobrovoljna ili nametnuta preraspodjela nadležnosti treba biti ireverzibilna. [...] ništa se ne protivi tome da nadležnost koja je prenesena ili preraspodijeljena u okviru reorganizacije javnih službi u konačnici postane predmet novog prijenosa ili nove preraspodjele pri sljedećoj reorganizaciji." ${ }^{120}$

Za razliku od odredbe članka 12. stavka 4. točke (c) opće direktive o javnoj nabavi $u$ vezi s ugovornom suradnjom javnih tijela, $u$ pogledu prijenosa nadležnosti nema sličnog ograničenja obavljanju djelatnosti na tržištu. Slično je zaključio i Sud u presudi Remondis, iako je odlučivao u pravnom okviru prethodne direktive o javnoj nabavi, s obzirom na to da nova direktiva tada još nije bila primjenjiva. ${ }^{121}$

Sud je tu iznimku i prije donošenja petog regulatornog javnonabavnog okvira utemeljio na odredbi članka 4. stavka 2. Ugovora o Europskoj uniji (dalje u tekstu: UEU) prema kojoj je Unija dužna poštovati nacionalne identitete država članica, koji su neodvojivo povezani s njihovim temeljnim političkim i ustavnim strukturama, uključujući regionalnu i lokalnu samoupravu. ${ }^{122}$ "[B]udući da ta raspodjela nadležnosti nije konačno utvrđena, zaštita koju dodjeljuje članak 4. stavak 2. UEU-a također se odnosi na reorganizaciju nadležnosti unutar

118 Neki autori tvrde da u slučaju prijenosa nadležnosti nedostaje prvo obilježje, tj. ugovorni odnos između teritorijalnih jedinica, pa već po toj osnovi ne bi bila riječ o ugovoru o javnoj nabavi (vidjeti Simon, D., Accord entre collectivités territoriales, Europe, br. 2, veljača 2017., str. 23).

119 Remondis (bilj. 24, t. 52).

120 Ibid., t. 53.

121 Ibid., t. 54.

122 Ibid., t. 40. 
države članice."123 Sud je, kao u slučaju ugovorne suradnje, navedenu iznimku obrazložio i nedostatkom elementa naplatnosti kao jednog od bitnih obilježja ugovora o javnoj nabavi. ${ }^{124}$

\subsection{Peto obilježje: nabava usluga, robe i radova}

Donošenjem četvrtog javnonabavnog regulatornog okvira 2004. tri posebne direktive o javnoj nabavi robe, radova i usluga prvi su put objedinjene u jednu opću direktivu o javnoj nabavi. ${ }^{125}$ Isti je slučaj i u petom regulatornom okviru iz $2014 .{ }^{126} \mathrm{U}$ tom je smislu razlikovanje triju predmeta nabave manje relevantno za pitanje opće primjenjivosti direktive, ali ono nije potpuno beznačajno s obzirom na to da se, među ostalim, na različite predmete nabave primjenjuju različiti pragovi vrijednosti, pa je u slučaju mješovite nabave ipak potrebno utvrditi glavni predmet nabave na temelju procijenjene vrijednosti različitih predmeta nabave obuhvaćenih istim ugovorom. ${ }^{127}$

Međutim, u sklopu ovog obilježja, ponajprije će se analizirati razlika ugovora o javnoj nabavi od drugih javnopravnih ugovora. Naime, javni naručitelj prilikom planiranja određenog projekta (primjerice, izgradnja ili proširenje zračne luke) ima na raspolaganju različite mogućnosti njegova strukturiranja. Isti projekt može se oblikovati kao ugovor o javnoj nabavi radova, kao koncesija ili pak kao (ugovorno ili statusno) javno-privatno partnerstvo. Nerijetko se u istom odnosu kombiniraju i sva tri oblika suradnje, ali sve ovisi o financijskim mogućnostima i željama javnog naručitelja/partnera.

Bitan kriterij razlikovanja između ugovora o javnoj nabavi i ugovora o koncesiji jest da se naknada sastoji isključivo od prava na iskorištavanje objekta ili usluge koja je predmet ugovora ili od tog prava i plaćanja koncesijske naknade. ${ }^{128}$ Nasuprot tomu, kod ugovora o javnoj nabavi, gospodarski subjekt prima naknadu izravno od javnog naručitelja za izvršenje predmeta nabave i ne preuzima gospodarsko iskorištavanje predmeta nabave. Druga posebnost ugovora o koncesiji jest da se po svojoj naravi mogu odnositi samo na radove i usluge, dok se ugovori o javnoj nabavi mogu odnositi na nabavu radova, robe i usluga.

\footnotetext{
${ }^{123}$ Ibid., t. 41.

124 Ibid., t. $42-46$.

125 Turudić, M., op. cit. u bilj. 4, str. $37-40$.

126 Ibid., str. 41.

127 Članci 3. - 5. opće direktive o javnoj nabavi.

128 Članak 5. stavak 1. direktive o koncesijama.
} 
Do donošenja direktive o koncesijama dodjela koncesija bila je potpuno (za usluge) ili samo djelomično (za određene radove) izvan područja primjene tadašnjih direktiva o javnoj nabavi, pa je razlikovanje tih dvaju pravnih instituta imalo znatne posljedice na razinu obveze javnog naručitelja u pogledu provedbe postupka javne nabave. ${ }^{129}$ Međutim, Sud EU-a u praksi je i na dodjele takvih koncesija proširio primjenu načela primarnog prava Unije (načela jednakog postupanja, zabrane diskriminacije, međusobnog priznavanja, proporcionalnosti i transparentnosti), čime je ujedno počelo stvaranje primarnog prava Unije o javnoj nabavi. ${ }^{130}$ Sada su koncesije uređene posebnom direktivom, pa su posljedice toga razlikovanja, osim u pogledu kvalifikacije pravnog odnosa, suštinski manje važne.

Što se tiče ugovora o javno-privatnom partnerstvu, riječ je o mješovitom ugovoru koji kombinira elemente ugovora o javnoj nabavi i ugovora o koncesiji s dodatnim oblicima suradnje između javnog naručitelja i privatnog partnera. ${ }^{131}$

129 Članak 17. Direktive 2004/18/EZ o usklađivanju postupaka za sklapanje ugovora o javnim radovima, ugovora o javnoj nabavi robe te ugovora o javnim uslugama (SL 2004., L 134, str. 114) (SL, posebno izdanje na hrvatskom jeziku, poglavlje 6. , svezak 1., str. 156). Međutim, člankom 18. Direktive 2004/17/EZ o usklađivanju postupaka nabave subjekata koji djeluju u sektoru vodnog gospodarstva, energetskom i prometnom sektoru te sektoru poštanskih usluga (SL 2004., L 134, str. 1) (SL, posebno izdanje na hrvatskom jeziku, poglavlje 6., svezak 1., str. 43), koncesije za usluge i radove za obavljanje djelatnosti u navedenim sektorima u cijelosti su stavljene izvan njezina područja primjene.

130 Vidjeti primjerice presude Komisija/Italija (C-272/91, EU:C:1994:167); Telaustria (C-324/98, EU:C:2000:669); Coname (bilj. 73); Parking Brixen (bilj. 45) i ANAV (bilj. 45); Knauff, M., Keine In-house-Vergabe einer Dienstleistungskonzession ohne Ausschreibung - Parking Brixen, Europäische Zeitschrift für Wirtschaftsrecht, vol. 23, 2005., str. 731 - 733; Braun, C.; Hauswaldt, C., Vergaberechtliche Wirkung der Grundfreiheiten und das Ende der Inländerdiskriminierung?, Europäische Zeitschrift für Wirtschaftsrecht, vol. 6, 2006., str. 176 - 178. Predmet direktive o koncesijama nisu koncesije za iskorištavanje općeg ili javnog dobra, koje su uređene posebnom Direktivom 2006/123/EZ o uslugama na unutarnjem tržištu (SL 2006., L 376, str. 36) (SL, posebno izdanje na hrvatskom jeziku, poglavlje 13., svezak 47., str. 160).

131 Hrvatski zakonodavac odlučio je tu vrstu ugovora urediti posebnim Zakonom o javno-privatnom partnerstvu (Narodne novine, br. 78/2012, 152/2014). U smislu članka 2. stavka 1. tog zakona “javno-privatno partnerstvo [...] je dugoročan ugovorni odnos između javnog i privatnog partnera predmet kojeg je izgradnja i/ili rekonstrukcija i održavanje javne građevine, u svrhu pružanja javnih usluga iz okvira nadležnosti javnog partnera". Javno-privatno partnerstvo može se organizirati u dvama oblicima: (i) isključivo kao ugovorno, na temelju ugovora o javno-privatnom partnerstvu, i (ii) kao statusno, u kojem su javni i privatni partner članovi zajedničkog trgovačkog društva koje je nositelj provedbe projekta javno-privatnog partnerstva. 
Na razini Unije još uvijek nema posebnog obvezujućeg pravnog akta koji bi uređivao isključivo tu vrstu ugovora. ${ }^{132}$ Zato se na te ugovore primjenjuje opća ili sektorska direktiva odnosno direktiva o koncesijama, ovisno o elementima koji čine glavni predmet ili pretežito obilježje konkretnog ugovora. ${ }^{133}$

\section{ZAKLJUČAK}

Cilj je ovog rada bio ispitati doseg pojma "ugovor o javnoj nabavi" u pravu Unije i njegova bitna obilježja, ponajprije u skladu s petim regulatornim okvirom iz 2014., kao i povezane iznimke od primjene zakonodavstva o javnoj nabavi koje je Sud EUa utvrdio u svojoj sudskoj praksi.

Treba zaključiti da je doseg pojma "ugovor o javnoj nabavi” vrlo širok, kako u pogledu osobnog tako i u pogledu materijalnopravnog područja primjene, pa tu kvalifikaciju načelno ne mogu izbjeći ni javnokorisni ugovori između dvaju javnih naručitelja u pogledu organiziranja javnih usluga ni (naizgled) besplatne činidbe izgradnje komunalne infrastrukture u korist lokalnih jedinica u sklopu realizacije privatnog projekta. Cilj je jasan - spriječiti različite prakse zaobilaženja primjene zakonodavstva o javnoj nabavi, kojemu je svrha otvoriti tržište javne nabave što većem tržišnom natjecanju.

Različiti oblici institucionalne i ugovorne suradnje javnih tijela dugo su bili "kolateralne žrtve" tako široke definicije, što je u mnogim aspektima ispravljeno posljednjim zakonodavnim paketom iz 2014. Naime, izvorna in house doktrina vrijedila je samo za institucionalne, "nizvodne" (downstream) oblike suradnje, tj. između osnivača i kontroliranog subjekta. Drugi oblici javno-javne suradnje ("uzvodna" (upstream) nabava, u kojoj kontrolirani subjekt nešto prima od svojeg osnivača; horizontalna nabava in house između subjekata koje kontrolira isti javni naručitelj i horizontalno-vertikalni ugovorni oblici suradnje javnih tijela,

132 Europska komisija donijela je u ožujku 2003. Smjernice za uspješna javno-privatna partnerstva, a 30. travnja 2004. i Zelenu knjigu o javno-privatnim partnerstvima i pravu Zajednice o ugovorima o javnoj nabavi i koncesijama (COM(2004) 327 final). Nakon toga Komisija je donijela Interpretativnu komunikaciju o primjeni prava Zajednice o javnoj nabavi i koncesijama na statusno javno-privatno partnerstvo (SL 2008., C 91, str. 4).

133 Vidjeti u tom smislu presude Club Hotel Loutraki i dr. (Cl45/08 i Cl49/08, EU:C:2010:247, t. 48 i 49) i Mehiläinen i Terveystalo Healthcare (C-215/09, EU:C:2010:807, t. 36); Krohn, M., op. cit. u bilj. 73, str. 19; Bauer, L., Das Ende der In-House-Vergabe, Zeitschrift für Vergaberecht und Beschaffungspraxis, vol. 10, 2005., str. 264. 
kao i njihovi međusobni prijenosi nadležnosti) nisu bili obuhvaćeni. Međutim, posljednja kodifikacija nije izričito uredila pitanje primjenjivosti iznimke u pogledu horizontalnih i obrnutih vertikalnih odnosa in house u slučaju subjekata koje zajednički kontrolira nekoliko javnih naručitelja, pa će u tom dijelu i dalje postojati pravna nesigurnost.

Izmjene donesene općom direktivom o javnoj nabavi 2014. pokazuju i blagi trend otvaranja mogućnosti sudjelovanja privatnog kapitala $u$ javnim projektima i poduzećima, kao i veće mogućnosti sudjelovanja kontroliranih subjekata na tržištu javne nabave u korist drugih javnih tijela koja nisu njihovi članovi, zbog čega su prema prijašnjem uređenju i sudskoj praksi mogli izgubiti svojstvo kontroliranog subjekta i u odnosu prema svojim članovima. Štoviše, uvođenjem egzaktnijih kriterija smanjeni su i rizici pogrešaka koji su dosad u praksi ugrožavali brojne javno-privatne i javno-javne projekte suradnje.

\section{LITERATURA}

Bauer, L., Das Ende der In-House-Vergabe, Zeitschrift für Vergaberecht und Beschaffungspraxis, vol. 10, 2005., str. $264-269$.

Bernal Blay, M. A., Un paso en falso en la interpretación del criterio del control análogo al de los propios servicios en las relaciones in house. Comentario a la STJCE de 19 de abril de 2007 (AS. C-295/05, Asemfo vs. Tragsa), Revista española de Derecho Administrativo, br. 137, 2008., str. 115 - 138.

Boesen, A., Stadtplanerische Neugestaltung als öffentlicher Bauauftrag, Europäische Zeitschrift für Wirtschaftsrecht, vol. 4, 2007., str. 117 - 123.

Braun, C.; Hauswaldt, C., Vergaberechtliche Wirkung der Grundfreiheiten und das Ende der Inländerdiskriminierung?, Europäische Zeitschrift für Wirtschaftsrecht, vol. 6, 2006., str. $176-178$.

Broussy, E.; Cassagnabère, H.; Gänser, C., Chronique de jurisprudence communautaire. Attribution sans mise en concurrence d'un marché public à une association sans but lucratif, Lactualité juridique: droit administratif, br. 6, 2015., str. 329 - 344.

Broussy, E.; Donnat, F.; Lambert, C., Marchés - In house et coopération intercommunale, Lactualité juridique: droit administratif, br. 42, 2008., str. 2336 - 2337.

Brown, A., Whether an Obligation on Certain Property Developers in Belgium to Provide Social Housing Gave Rise to a Public Works Contract Within Directive 2004/18: the Ruling of the EU Court of Justice in Joined Cases C-197/11 and C-203/11 Libert and Others v Flemish Government, Public Procurement Law Review, br. 6, 2013., str. NAl64 - NAl72.

Daniel, É., Organisme de droit public, Europe, br. 2, veljača 2015., str. 30 - 32. 
Clarke, C. M., The CJEU's Evolving Interpretation of In-House Arrangements under the EU Public Procurement Rules: A Functional or Formal Approach?, European Procurement \& Public Private Partnership Law Review, vol. 10, br. 2, 2015., str. $111-125$.

Dreyfus, J.-D., Une délégation de tâche de droit public est-elle soumise au droit des marchés publics?, L'actualité juridique: droit administratif, br. 30, 2013., str. 1751 - 1753.

Durviaux, A. L., La coopération horizontale, Revue trimestrielle de droit européen, br. 2, 2013., str. $346-348$.

Falle, J., Hamburg again: shared services and public sector cooperation in the case of Technische Universitat Hamburg-Harburg v Datenlotsen Informationssysteme GmbH, Public Procurement Law Review, br. 5, 2014., str. NA123 - NA132.

Frenz, W., Ausschreibungspflicht bei Anteilsveräußerungen und Enkelgesellschaften, Neue juristische Wochenschrift, vol. 37, 2006., str. 2665 - 2668.

Fruhmann, M., Der gemeinschaftsrechtliche Vertragsbegriff, In-House und das Transparenzprinzip, Zeitschrift für Vergaberecht und Beschaffungspraxis, vol. 3, 2008., str. $73-80$.

Gaßner, M., Das Open-house-Urteil des EuGH - Ein Geschenk für kreative Beschaffer, Neue Zeitschrift für Sozialrecht, vol. 20, 2016., str. 767 - 770.

Hamerl, T., In-house-Vergabe bei gemeinsamer Kontrolle über den Auftragnehmer, Zeitschrift für Vergaberecht und Beschaffungspraxis, vol. 3, 2013., str. 122 - 123.

Hojnik, J., Sporazumi med javnimi subjekti v luči pravil EU o javnem naročanju, Davčno-finančna praksa: davki, finance, zavarovalništvo, br. 2, 2013., str. 25 - 28.

Janssen, W. A., The Institutionalised and Non-Institutionalised Exemptions from EU Public Procurement Law: Towards a More Coherent Approach?, Utrecht Law Review, vol. 10, br. 5, 2014., str. 168 - 186.

Kahlert, H., Auftragswert bei der Vergabe städtebaulicher Entwicklungsaufträge: Einbeziehung von Zahlungen privater Erwerber, European Law Reporter, br. 2, 2007. str. $69-73$.

Krohn, M., Neues zu den Public Private Partnerships: In-house-Vergaben und Rechtsschutz gegen De-facto-Vergaben, European Law Reporter, br. 1, 2005., str. 18 - 23.

Knauff, M., Keine In-house-Vergabe einer Dienstleistungskonzession ohne Ausschreibung - Parking Brixen, Europäische Zeitschrift für Wirtschaftsrecht, vol. 23, 2005., str. $727-733$.

McGowan, D., A Contract or Not? A Note on Asociación Profesional de Empresas de Reparto y Manipulado de Correspondencia v Administracion General del Estado (Case C-220/06), Public Procurement Law Review, br. 5, 2008., str. NA204 - NA208. 
McGowan, D., Further Clarification of Permissible Public Cooperation: Piepenbrock Dienstleistungen GmbH \& Co. KG v Kreis Düren, Public Procurement Law Review, br. 6, 2013., str. NAI58 - NAl60.

Meister, M., Qualification du contrat “in house”, Europe, br. 7, srpanj 2014., str. $27-28$

Müller, T., Interkommunale Zusammenarbeit im Weg der In-House-Vergabe?, Zeitschrift für Vergaberecht und Beschaffungspraxis, vol. 7-8, 2007., str. 197 - 204.

Mužina, A., Razjasnitev uporabe notranjih (in-house) razmerij pri izvajanju javnih naročil/koncesij, Pravna praksa, br. 48, 2012., str. $21-22$.

Pedersen, K.; Olsson, E., Commission v Germany - a new approach to in-house providing?, Public Procurement Law Review, br. 1, 2010., str. 33 - 45.

Pedersen, K.; Olsson, E., Azienda: the creation of an exemption from public procurement law, Public procurement law review, br. 6, 2013., str. $225-235$.

Probst, P. M., Gemeinnützigkeit schützt nicht vor Vergabepflicht!, European Law Reporter, br. 3, 2014., str. $101-105$.

Probst, P.; Wurzel, G., Zulässigkeit von In-house-Vergaben und Rechtsfolgen des Abschlusses von vergaberechtswidrigen Verträgen. (Asemfo / Tragsa, EuGH vom 19. April 2007, C-295/05 und Kommission / Deutschland, Schlussanträge GA Trstenjak vom 28. März 2007, C-503/04), European Law Reporter, br. 7-8, 2007., str. $257-265$.

Rabolt, K., Die so genannte Inhouse-Beziehung zwischen Gebietskörperschaft und Dienstleistungsersteller als Ausnahme vom Ausschreibungswettbewerb, u: Cox, H. (ur.), Ausschreibungswettbewerb bei öffentlichen Dienstleistungen, Nomos, Baden-Baden, 2003., str. 107 - 115.

Schabel, T., Vergaberechtsfreiheit des Open-House-Modells, Europäische Zeitschrift für Wirtschaftsrecht, vol. 18, 2016., str. $705-709$.

Simon, D., Accord entre collectivités territoriales, Europe, br. 2, veljača 2017., str. $23-24$.

Steinberg, P., Öffentlicher Auftraggeber als Mehrheitsaktionär des Auftragnehmers, Europäische Zeitschrift für Wirtschaftsrecht, vol. 12, 2006., str. 375 - 380.

Turudić, M., Pravo javne nabave, Narodne novine, Zagreb, 2017.

Wagner, O.; Görs, B., Ausschreibungspflichtigkeit von Investorenwettbewerben, Neue Zeitschrift für Verwaltungsrecht, vol. 8, 2007., str. 900 - 902.

Wiggen, J., Public procurement rules and cooperation between public sector entities: the limits of the in-house doctrine under EU procurement law, Public Procurement Law Review, br. 5, 2011., str. 157 - 172. 
Würfel, W.; Butt, M., Ausschreibungspflicht für städtebauliche Verträge - oder: Schaut man einem geschenkten Gaul doch ins Maul?, Neue Zeitschrift für Verwaltungsrecht, vol. 2, 2003., str. $153-158$.

\section{IZVORI}

\section{Pravni akti}

Ugovor o Europskoj uniji (SL 2016., C 202, str. 13)

Ugovor o funkcioniranju Europske unije (SL 2016., C 202, str. 47)

Direktiva 2004/18/EZ Europskog parlamenta i Vijeća od 31. ožujka 2004. o usklađivanju postupaka za sklapanje ugovora o javnim radovima, ugovora o javnoj nabavi robe te ugovora o javnim uslugama (SL 2004., L 134, str. 114) (SL, posebno izdanje na hrvatskom jeziku, poglavlje 6., svezak 1., str. 156).

Direktiva 2004/17/EZ Europskog parlamenta i Vijeća od 31. ožujka 2004. o usklađivanju postupaka nabave subjekata koji djeluju u sektoru vodnog gospodarstva, energetskom i prometnom sektoru te sektoru poštanskih usluga (SL 2004., L 134, str. 1) (SL, posebno izdanje na hrvatskom jeziku, poglavlje 6., svezak 1., str. 43)

Direktiva 2006/123/EZ Europskog parlamenta i Vijeća od 12. prosinca 2006. o uslugama na unutarnjem tržištu (SL 2006., L 376, str. 36) (SL, posebno izdanje na hrvatskom jeziku, poglavlje 13., svezak 47., str. 160)

Direktiva 2014/23/EU Europskog parlamenta i Vijeća od 26. veljače 2014. o dodjeli ugovorâ o koncesiji (SL 2014., L 94, str. 1, i ispravak SL 2015., L 114, str. 24)

Direktiva 2014/24/EU Europskog parlamenta i Vijeća o javnoj nabavi i o stavljanju izvan snage Direktive 2004/18/EZ (SL 2014., L 94, str. 65; ispravci SL 2015., L 275, str. 68, i SL 2016., L 311, str. 26)

Direktiva 2014/25/EU Europskog parlamenta i Vijeća od 26. veljače 2014. o nabavi subjekata koji djeluju u sektoru vodnog gospodarstva, energetskom i prometnom sektoru te sektoru poštanskih usluga i stavljanju izvan snage Direktive 2004/17/EZ (SL 2014., 94, str. 243)

Smjernice za uspješna javno-privatna partnerstva, http://ec.europa.eu/regional_policy/sources/docgener/guides/ppp_en.pdf (29. rujna 2017.)

Zakon o financiranju vodnog gospodarstva (Narodne novine, br. 153/2009, 90/2011, 56/2013, 154/2014, 119/2015, 120/2016)

Zakon o javnoj nabavi (Narodne novine, br. 120/2016) 
Zakon o javno-privatnom partnerstvu (Narodne novine, br. 78/2012, 152/2014)

Zakon o komunalnom gospodarstvu (Narodne novine, br. 36/1995, 70/1997, 128/1999, 57/2000, 129/2000, 59/2001, 26/2003, 82/2004, 110/2004, 178/2004, 38/2009, 79/2009, 153/2009, 49/2011, 84/2011, 90/2011, 144/2012, 94/2013, 153/2013, 147/2014, 36/2015)

Zakon o lokalnoj i područnoj (regionalnoj) samoupravi (Narodne novine, br. 33/2001, 60/2001, 129/2005, 109/2007, 125/2008, 36/2009, 36/2009, 150/2011, 144/2012, 19/2013, 137/2015)

Zakon o obveznim odnosima (Narodne novine, br. 35/2005, 41/2008, 125/2011, $78 / 2015)$

Zakon o preuzimanju dioničkih društava (Narodne novine, br. 109/2007, 36/2009, 108/2012, 90/2013, 99/2013, 148/2013)

Zakon o prostornom uređenju (Narodne novine, br. 153/2013)

Zakon o trgovačkim društvima (Narodne novine, br. 111/1993, 34/1999, 121/1999, 52/2000, 118/2003, 107/2007, 146/2008, 137/2009, 125/2011, $152 / 2011,111 / 2012,68 / 2013,110 / 2015)$

\section{Sudska praksa}

Komisija/Italija, C-3/88, EU:C:1989:606

Grifoni/EZAE, C-330/88, EU:C:1991:95

Komisija/Italija, C-272/91, EU:C:1994:167

Komisija/Belgija, C-87/94, EU:C:1996:161

Teckal, C-107/98, EU:C:1999:562

Unitron Scandinavia i 3-S, C-275/98, EU:C:1999:567

Telaustria, C-324/98, EU:C:2000:669

ARGE Gewässerschutz, C-94/99, EU:C:2000:677

Ordine degli Architetti i dr., C-399/98, EU:C:2001:401

Adolf Trulley, C-373/00, EU:C:2003:110

Komisija/Španjolska, C-214/00, EU:C:2003:276

Stadt Halle RPL Lochau, C-26/03, EU:C:2005:5

Komisija/Španjolska, C-84/03, EU:C:2005:14

Coname, C-231/03, EU:C:2005:487

Parking Brixen, C-458/03, EU:C:2005:605

Komisija/Austrija, C-29/04, EU:C:2005:670 
ANAV, C-410/04, EU:C:2006:237

Carbotermo i Consorzio Alisei, C-340/04, EU:C:2006:308

Auroux i dr., C-220/05, EU:C:2007:31

Asociación Nacional de Empresas Forestales, C-295/05, EU:C:2007:227

Komisija/Italija, C-382/05, EU:C:2007:445

Komisija/Italija, C-119/06, EU:C:2007:729

Asociación Profesional de Empresas de Reparto y Manipulado de Correspondencia, C220/06, EU:C:2007:815

Frigerio Luigi \& C., C-357/06, EU:C:2007:818

Komisija/Irska, C-532/03, EU:C:2007:801

Coditel Brabant, C-324/07, EU:C:2008:621

Komisija/Njemačka, C-480/06, EU:C:2009:357

Sea, C-573/07, EU:C:2009:532

CoNISMa, C-305/08, EU:C:2009:807

Helmut Müller, C-451/08, EU:C:2010:168

Ordine degli Ingegneri della Provincia di Lecce i dr., C-159/11, EU:C:2012:817

Econord, C182/11 i C183/11, EU:C:2012:758

Eric Libert i dr., C-197/11 i C-203/11, EU:C:2013:288

Piepenbrock, C-386/11, EU:C:2013:385

Swm Costruzioni 2 i Mannocchi Luigino, C 94/12, EU:C:2013:646

Datenlotsen Informationssysteme, C-15/13, EU:C:2014:303

Centro Hospitalar de Setúbal, C-574/12, EU:C:2014:2004

Azienda sanitaria locale n. 5 "Spezzino” i dr., C-113/13, EU:C:2014:2440

Data Medical Service, C-568/13, EU:C:2014:2466

Partner Apelski Dariusz, C-324/14, EU:C:2016:214

Falk Pharma, C-410/14, EU:C:2016:399

Undis Servizi, C-553/15, EU:C:2016:935

Remondis, C-51/15, EU:C:2016:985

Borta, C-298/15, EU:C:2017:266 
Summary

\section{Danijel Stanković}

\section{THE NOTION OF "PUBLIC CONTRACT" IN EU LAW AND RELATED EXCEPTIONS TO THE APPLICABILITY OF PUBLIC PROCUREMENT LEGISLATION}

The subject-matter of this paper is the notion of "public contract" in EU law as functionally interpreted by the Court of Justice of the European Union, as well as related exceptions to the applicability of the 2014 public procurement legislation package, with particular regard to in-house awards, cooperation between contracting authorities and transfers of powers.

The analysis follows each of the five main elements of a public contract relating to (i) the existence of a contract, (ii) pecuniary interest, (iii) written form, (iv) the parties being two legally distinct persons and (v) the object being the provision of works, supplies or services.

The main conclusion of the research is that the broad and functional interpretation of each of the main requirements by the CJEU, together with a strict interpretation of the available exceptions to those requirements, aims at preventing circumventions of the $E U$ procurement rules. However, due to that approach, various forms of public-public cooperation were for a long time collateral casualties. The 2014 legislative framework provides additional clarity and legal certainty in that respect, but there are still certain situations which do not appear to be covered, which will require interpretation by the CJEU in the future.

Key words: public procurement, public contract, in house award, cooperation between contracting authorities, transfer of powers and responsibilities for the performance of public tasks

Danijel Stanković, mag. iur., LL.M. Finance (Institute for Law and Finance, Goethe-Universität, Frankfurt am Main); LL.M. de droit français et de droit européen (Université Paris 1 Panthéon-Sorbonne), Lawyer-linguist, Court of Justice of the European Union, TB/16LB0022, Rue du Fort Niedergrünewald, L-2925 Luxembourg; danijel.stankovic@curia.europa.eu;

ORCID ID: orcid.org/0000-0003-0551-7394

The views and opinions expressed in this paper are those of the author and in no way represent the official position of the Court of Justice of the EU where the author works. 
